\title{
Systemic and Idiosyncratic Risk in EU-15 Sovereign Yield Spreads after Seven Years of Monetary Union.
}

\author{
Marta Gómez-Puig* \\ Economic Theory Department. University of Barcelona. Av. Diagonal 690. Barcelona 08034. Spain. \\ T:34-934.020.113.Fax: 34-934.039.082.E-mail:marta.gomezpuig@,ub.edu.
}

\begin{abstract}
The market capitalization of international bond markets is much larger than that of international equity markets. However, compared to the large body of literature on international equity market linkages, there are few empirical studies of bond systemic risk or international bond market co-movements. However, the extent of international bond market linkages does merit investigation, as it may have important implications for the cost of financing fiscal deficit, monetary policymaking independence, modelling and forecasting long-term interest rates, and bond portfolio diversification. In this paper, we investigate the relative influence of systemic and idiosyncratic risk factors on yield spreads over 10-year German government securities during the seven years after the beggining of Monetary Integration. We estimate both panel regressions for the two group of EU-15 countries (EMU and non-EMU) and specific-country regressions for the nine and three countries in the two groups. All estimations include both domestic (differences in market liquidity and credit risk) and international risk factors. The results present clear evidence that it is idiosyncratic rather than systemic risk factors that mostly drive the evolution of 10-year yield spread differentials over Germany in all EMU countries during the seven years after the beginning of Monetary Integration. Conversely, in the case of non-EMU countries, adjusted yield spreads (corrected from the foreign exchange factor) are influenced more by systemic risk factors. The fact that these countries do not share a common Monetary Policy might explain these results, which may show that government bonds from EMU countries have a better safe-haven status compared to non-EMU countries.
\end{abstract}

Keywords: Monetary integration. Sovereign debt markets. Systemic and Idiosyncratic risk. JEL Classification: E44, F36, G15.

\footnotetext{
This paper is based upon work supported by the Government of Spain and FEDER under grant number SEJ200763298. I thank participants in seminars at X Applied Economics Meeting, the X Conference on International Economics, the 7th INFER workshop on International Economics and the European Financial Management 2008 annual meeting in Athens for valuable comments. I would also like to thank the Researchers at the European Central Bank Financial Markets Division for their hospitality during the summer of 2008 and their insightful comments on a previous version of the paper, and Analistas Financieros Internacionales, S.A. who have kindly provided part of the data used in the empirical analysis. Finally, I would like to give special thanks to an anonymous referee for his/her wise comments. I alone am responsible for any errors remaining in the final version.
} 


\section{Introduction.}

The market capitalization of international bond markets is larger than that of international equity markets. However, compared to the large body of literature on international equity market linkages (see Bessler and Yang, 2003), there are few empirical studies of bond systemic risk or international bond market linkages (Smith, 2002 and Barr and Priestley, 2004). However, the extent of international bond market linkages does merit investigation, as it may have important implications for the cost of financing fiscal deficit, monetary policymaking independence, modeling and forecasting long-term interest rates, and bond portfolio diversification.

Conversely, more has been written on emerging countries, where a very important question in the study of spread co-movements is the analysis of the relative influence of fundamental variables on that behavior (see Cifarelli and Paladino, 2006). Economies are related through trade and financial flows, and shifts in the economic fundamentals of one country may affect its neighbours. However, in periods of growing uncertainty, changes in market sentiment may go beyond fundamentals and generate "contagion phenomena"1. Calvo and Reinhart (1996), Masson (1999) and, more recently, Bekaert, Harvey and Ng (2005) draw a distinction between fundamentals-based contagion, which arises when the "infected country" is connected to others via trade and/or financial links, and pure contagion, which is due to a shift in market sentiment without (or beyond) links in economic fundamentals. Therefore, even though there is far more literature on emerging than on developed economies, in both cases, it is well established that bond markets in different countries tend to move together, i.e. bond prices and returns are positively correlated across countries. Some of the early attempts to investigate this issue are Clare et al. (1995) who provided insight into the significance of international bond market linkages for bond portfolio diversification, and Ilmanen (1995), whose evidence suggested that excess returns of long international bonds were highly correlated implying, in turn, international bond market integration. More recently, Hunter and Simon (2005), using a bivariate conditional correlation GARCH model, examine the lead-lag and

\footnotetext{
1 In the context of developed countries, Favero and Giavazzi (2002) study the presence of non-linearities in the propagation of financial shocks (devaluation expectations) among the countries that were member of the Exchange Rate Mechanism of the EMS.
} 
contemporaneous relationships between 10-year US government bond returns and 10-year UK, German, and Japanese government bond returns. They find that the mean and volatility of the US bond market lead the mean and volatility of both German and Japanese bond markets, whilst there is no significant lead-lag relation between the US and UK bond markets. Volatility spillover from world bond markets into individual bond markets has also focused the attention of the literature. In particular, Christiansen (2007) finds strong statistical evidence of volatility spillover from the US and aggregate European bond markets into individual European bond markets. For EMU countries, the US volatility spillover effects are rather weak (in economic terms) whereas the European volatility-spillover effects are strong. Earlier studies used co-integration analysis to document the co-movement of international bonds markets (see De Gennaro et al.(1994), Clare at al. (1995), Barassi et al. (2001), Smith (2002) or Driessen et al. (2003)). These co-integration analyses do not, however, examine co-movement in the underlying factors determining bond yields. Ilmanen (1995) suggests a number of factors determining international bond returns, and finds that a small set of global (world) factors accounts for the predictable variation in bond returns and their crosscountry correlation. In particular, wealth-dependent risk-aversion of bond investors appears to be an important source of international co-movement. Barr and Priestley (2004) also find that bond returns in different countries are predictable over time; based on an international CAPM they find that 70 per cent of the variation in expected returns is due to world risk factors while the remaining 30 per cent is due to local country-specific risk factors. They interpret this result as indicating that national bond markets are only partially integrated into world markets.

In this context, this study contributes to the literature in several aspects. First, the main goal of this paper is to assess the relative importance of systemic/world risk factors or idiosyncratic/local risk factors in explaining yield spreads in EU-15 countries (both EMU and non-EMU participating) after the introduction of the common currency. In our opinion, the recent literature overestimates the impact of systemic risk on the behaviour of yield differentials in EMU countries (see Favero, Pagano and Von Thadden (2007); Geyer, Kossmeier and Pischer (2004) or Pagano and Von Thadden (2004), among others). Certainly, yield evolution depends on both world and local risk factors, i.e. systemic and idiosyncratic risk. However, when differentials between yields are taken, 
the impact of world or common risk factors should mostly cancel out. Second, our empirical estimation uses a broader dataset than in previous studies. To the best of our knowledge, this is the first empirical study that implements an analysis of the effects of Monetary Union on the relative importance of systemic and idiosyncratic risk in EU-15 governments' bonds yield spreads with daily data for such a long period of time (data set covers seven years since the beginning of EMU, from 1999 to 2005). Third, in this paper, the analysis goes beyond EMU countries and studies the influence of Monetary Union in the relative importance of the different sources of risk. Therefore, our final goal is to assess the relative importance of the two kinds of risk factors in yield differentials in two groups of EU-15 countries (EMU and non-EMU participating) during the first seven years of Monetary Integration. So, in order to be able to compare the results, we implement a similar methodology (both a panel and a country-specific analysis) as in our previous papers (Gómez-Puig, 2006, 2008a and 2008b), where dataset covered the period 1999-2001.The rest of the paper is organized as follows. Section 2 summarizes the related literature on this topic. Section 3 explains the methodology, whilst data and explanatory variables are described in Section 4. The model is explained in Section 5. Finally, Section 6 reports the results and section 7 draws the main conclusions.

\section{Related Literature.}

Some recent literature (using other approaches) has assessed the relative importance of systemic and idiosyncratic risk in EMU sovereign yield spreads (see Geyer, Kossmeier and Pischler (2004), Pagano and von Thadden (2004) or Favero, Pagano and von Thadden (2007)). Nevertheless, our results differ in suggesting that it is idiosyncratic factors that mostly drive yield differentials, and that systemic risk plays only a marginal role. In this sense, Geyer et al. estimate a multi-issuer statespace version of the Cox-Ingersoll-Ross (1985) model of the evolution of bond-yield spreads (over Germany) for four EMU countries (Austria, Belgium, Italy and Spain). Their main findings are (i) one single ("global") factor explains a large part of the movement of all four processes, (ii) idiosyncratic country factors have almost no explanatory power, and (iii) the variation in the single global factor can to a limited extent be explained by EMU corporate-bond risk, but by nothing else. 
The most striking finding in Geyer et al. (2004) is the virtual absence of country-specific yieldspread risk. On the other hand, despite the considerable differences in the methodology and data used, Geyer et al. and Pagano and von Thadden (2004) analysis agree that yield differentials under EMU are driven mainly by a common risk (default) factor and suggest that liquidity differences have at best a minor role in the time-series behavior of yield spreads. Our results differ clearly in suggesting that it is idiosyncratic factors that mostly drive yield differentials. Nevertheless, it is important to note that Geyer et al.'s measurement of liquidity variables is more indirect than ours, as they do not use data on bid-ask spreads; furthermore, and on the other hand, Pagano and von Thadden work with data taken from the Euro MTS trading platform which includes only the transactions made through this platform and not in the whole market, as we do in our paper. However, Favero, Pagano and von Thadden (2007) recognize that aggregate (global) risk and liquidity may interact with each other in non-trivial manners, which allows us to accept that their results are consistent with the ones presented in this paper. In particular, these authors propose a simple asset-pricing model with exogenous transactions and endogenous liquidity demand, where a bond's liquidity premium depends both on its transaction cost and on investment opportunities. Their model predicts that yield differentials should increase in both liquidity and aggregate risk, with an interaction term of the opposite sign. The empirical evidence they find support their predictions. Therefore, according to them a direct estimation of the impact of liquidity on prices, i.e. an estimation that ignores the indirect effect caused by the interaction with world-wide risk, is likely to underestimate its impact, which can be amplified or dampened by aggregate risk. The sign of this interaction term depends on the covariation between the cost of illiquidity and aggregate risk $^{2}$ Moreover, their "liquidity risk view" highlights that liquidity is priced not only because it creates trading costs but also because it is itself a source of risk since it changes unpredictably over

\footnotetext{
2 Their model is based on the idea that the demand for liquidity responds both to the magnitude of trading costs and to the availability of outside investment opportunities. First, investors are less inclined to trade securities with larger trading costs. Second, they are less likely to liquidate securities when outside investment opportunities are less attractive, a situation which is assumed to coincide with increased aggregate risk. As a result, when risk is expected to increase, investors' demand for liquidity abates, and the premium they place on more liquid securities declines. Therefore, although in general investors value liquidity, they value it less when risk increases. Their estimates support their intuition.
} 
time. Since investors care about returns net of trading costs, the variability of trading costs affects the risk of a security. So, current liquidity is a predictor of future liquidity risk, and is therefore priced. This approach is then consistent with the self-fulfilling nature of liquidity that, following Economides and Siow (1988), Gómez-Puig (2006, 2008a, and 2008b) put forward. The central intuition is that as long as "ex-ante" traders prefer bigger and liquid markets (because they will present lower price volatility, bigger scale economies and higher probability of a favorable match) to small and illiquid markets, liquidity will be "self-reinforcing". That is, since traders prefer to participate in liquid markets, more traders will participate in them, and more liquid they will be. In other words, liquidity will be self-fulfilling because deals create positive externalities by increasing the depth of the secondary market, and thus the price of a future resale. Therefore, if liquidity is self-fulfilling, the proxies of market liquidity might present a non-linear relationship, i.e. a liquid/illiquid market might lead to an increasingly lower/higher liquidity premium. This non-linear behaviour will also be analysed in this paper. In order to compare the results with those obtained in Gómez-Puig (2008a and 2008b), proxies for market liquidity present a specific nonlinear structure: "a quadratic form". In our opinion, this is a right way to capture self-fulfilling effects in liquidity, even though it is not the only one. For example, in the econometric model of contagion advanced in Pesaran and Pick (2007), self-fulfilling effects are generated by multiple equilibria (along the same lines as in Masson (1999)), and are created by the inclusion of endogenous dummy variables.

\section{Methodology.}

An important issue for assets that are traded internationally is the extent to which the time-varying compensation that investors require for accepting a risky payoff is the extent to which this compensation is driven by world, rather than domestic, factors, i.e. the extent to which the domestic market is integrated into world markets. Several papers have investigated this issue but, as we noted above, most of them focus on equity markets. In this paper we ask what can be learned from European bond markets after Monetary Integration and, in particular, we will assess the relative importance of systemic or idiosyncratic risk factors in explaining European Union-15 countries' yield spreads after the introduction of the Euro. 
One way to study this is to assume that markets are fully integrated, and to test the restrictions generated by Asset Pricing Models (APMs): a rejection is interpreted as a rejection of the joint hypothesis of full integration and the APM (Dumas and Solnik, 1995). However, this integration assumption reflects a fundamental difficulty in international asset pricing, since current APMs can accommodate only the two extremes of integration or segmentation, and both of these will be rejected if markets are only partially integrated. Some combination of the polar models is required in order to deal with partially integrated markets. The work by Bekaert and Harvey $(1995,1997)$ and Barr and Priestley (2004) is in this vein and allows the level of integration to change over time by combining the polar models. In this paper, we use a model that draws on Barr and Priestley (2004) and Favero, Pagano and von Thadden (2007) in order to investigate the level of integration in the European Union bond markets.

Therefore:

We assume that yields $\left(y_{i, t}\right)$ for country $i$ are related to world and local information variables as follows (see Barr and Priestley):

$y_{i, t}=a_{i}+b^{\mathbb{W}} Z_{i} W_{i, t} b_{i}^{L_{i}} Z^{L_{i, t}}+b^{W L} L_{i}\left[Z^{W}{ }_{i, t} \cdot Z^{L_{i, t}}\right]+\varepsilon_{i, t}$

Where $Z^{W}{ }_{i, t}$ represents the world variables, $Z^{L}{ }_{i, t}$ represents local variables for country $i, Z^{W}{ }_{i, t}$. $Z^{L_{i, t}}$ represents the interaction between them, and $\varepsilon_{i, t}$ is an error term. Following Favero, Pagano and von Thadden $(2007)^{3}$ we allow yields to be explained in terms of exogenous risk premiums (specifically, banking risk premiums in the United States) which will appear in the regression both linearly and interacting with the domestic risk variables. The interaction term needs to be included to avoid the omitted variables problem. Equation (1) is consistent with a range of asset pricing models, and with any level of integration. If a market is fully integrated the local variables should be absent from it. Similarly, if it is completely segmented, the world variables will be absent.

\footnotetext{
3 These authors point out that a look at the time-series behaviour of Euro-area yield differentials suggests that yield differentials tend to fluctuate together, much more than measures of liquidity or default risk do. This suggests that domestic factors alone cannot be the full answer, and that there must be other factors driving yield differentials. Such factors are likely to be related to international investment opportunities or global risk perceptions.
} 
However, it should be easy to understand that when we take differences between yields, i.e. we calculate yield spreads $\left(S_{i, t}\right)$ for country $i$ over Germany, the effect of world risk variables should mostly disappear or cancel out. So, yield spreads will mostly depend on local or domestic risk factors. However, due to the recent debate in the literature, we will assess the impact of both kinds of variables on yield spreads by assuming that they are related to world and local information variables and to the interaction between them, as follows:

$S_{i, t}=a_{i}+b^{W_{i}} Z^{W_{i, t}}+b^{L_{i}} Z^{L_{i, t}}+b^{W L} L_{i}\left[Z^{W}{ }_{i, t} \cdot Z^{L_{i, t}}\right]+\varepsilon_{i, t}$

The yield patterns are reflected in their correlation across countries. All EU-15 (EMU and nonEMU participating) country yields are fairly highly correlated with the U.S. 10-year yields. Table 1 shows that the cross-sectional average correlation is 0.75 , providing weak evidence of integration. Therefore, the average contribution of world factors to domestic returns across the thirteen countries we study (Luxembourg and Greece are excluded from our sample) is $75 \%$. This level seems surprisingly low in view of the absence of impediments to cross-country investment. Nevertheless, the figures in this table show a very high and similar correlation across EU-15 countries' yields (the average correlation with Germany 10-year yields is 0.98 and 0.99 if we consider only EMU-countries), except in the case of the United Kingdom which presents an average level of correlation of 0.84 with German yields and one of 0.82 with the rest of EU-15 countries in our sample. This evidence supports the idea (see Gómez-Puig 2008b) that outside the Euro-area, the Currency Union has enhanced the "singularity" of the debt markets because their securities are still denominated in their own currency. In particular, the British market, which before EMU was not only one of the most important European debt markets, but was also the European market with the highest share of foreign assets as a function of total financial wealth (see Adjaouté et al., 2001 or Tesar and Werner, 1995), is surely the one that has capitalized most on this new advantage and has attracted a significant volume of funds. 
Table 2 shows the correlation between spreads (adjusted spreads or spreads corrected from the exchange rate factor in the case of non-EMU countries $^{4}$ ) and the world risk variable used to capture international risk (the differential between 10-year fixed interest rates on US swaps and the yield on 10-year Moody's Seasoned AAA US corporate bonds, USSPREAD $D_{i t}$. This table clearly shows that the correlation with global risk factors can mostly be ignored when differentials are taken in EMU countries (the average value is -0.04 , and Portugal is the only country that presents a slight positive average value of 0.107$)$. In the case of non-EMU countries we find very different results. The average correlation between the variable adjusted spread (the yield spread corrected from the foreign exchange factor) and the global risk factor is 0.4 . The country with the lowest coefficient is Denmark, whilst the country with the highest one is the United Kingdom (0.56) Finally, Table 3 presents the evolution of yield spreads or adjusted yield spreads (in the case of non-EMU countries) during three sub-periods into which the whole sample has been broken down: 19992000, 2001-2002, and 2003-2005. It can be observed that, within the EMU, yield differentials experience a high decrease during the last three years of the period. During the third sub-period, 2003-2005, except in the case of Italy, the average values are less than half the value they present for the whole period. In the case of non-EMU countries, except in the case of Denmark which only presents a negative value during the third period (the fact that the exchange rate regime, in this country, links the evolution of its currency to the Euro explains why Denmark's yield spreads present a behavior which is closer to EMU-countries than to non-EMU countries), the other two countries (Sweden and the United Kingdom) display negative adjusted spread values in the four periods. Nevertheless, this negative differential is lower at the end of the sample than during the first years following the introduction of the Euro. Therefore, market capitalization of the advantage presented by these markets over Euro-area debt markets in terms of the benefits derived from portfolio diversification and risk reduction was higher in the first years after the beginning of Monetary Union. On the other hand, it can also be observed that volatility (measured by the

\footnotetext{
${ }^{4}$ As we will explain later in this paper, following Favero, Giavazzi and Spaventa (1997), we will correct non-EMU spreads by estimating the foreign exchange factor as the differential between the 10 year swap rate in the currency of denomination of the bond and the 10 year swap rate in Deutsche marks.
} 
standard deviation) has sharply decreased in the last period of the sample for most of the European countries (the only exceptions are Finland, the Netherlands and Ireland) These observations suggest that three separate estimations for each one of the sub-periods will present wider information than a single estimation for the complete sample. So, we will estimate the model for the four samples (the whole period and the three sub-periods) in order to compare the results. Figures 1 and 2 display the evolution of 10-year yields and 10-year yield spreads over Germany, respectively, for EMU countries. These figures show, on the one hand, the high co-movement presented by 10-year yields during the first seven years of Currency Union (figure 1) and, on the other, the lower co-movement and higher volatility presented by yield spreads throughout the sample (figure 2). The evolution of the same variables in the case of the three non-Euro countries included in our sample is displayed in figures 3 and 4. In particular, these figures show that the country with the highest spread over Germany is the United Kingdom, while the country whose government's yields follow those of Germany most closely is Denmark. Finally, figure 5 presents the evolution of 10-year swap spreads over Germany of the three countries in our sample that do not participate in the Euro (since, as it will be explained, we will use the 10-year swap differential over Germany as an approximation of currency risk), whilst figure 6 displays the evolution of the dependent variable we will use in the case of these countries: the spread corrected from the exchange rate risk factor which we will call "adjusted spread" (note that this variable presents a negative value in the case of Sweden and the United Kingdom throughout the sample).

As discussed by Favero et al. (1997) a direct measure of the component of yield differentials not related to exchange rate factors can be obtained by comparing the yields of assets issued by two different states in two different currencies (say, one in Spanish pesetas, the other in D-marks) and the yield spreads in the same currencies and with the same life to maturity issued by the same (nongovernment) subject, or by two otherwise comparable issuers (in the second case, apart from the exchange rate risk, other factors influencing yield spreads can then be ignored when differences are taken). Candidates for this measure are: (1) long-term bonds issued by the same supra-national organization (such as the World Bank or the European Investment Bank), (2) long-term bonds issued by the private sector, and (3) the fixed interest rates on swap contracts. However, on balance, 
the drawbacks of the interest differential on supranational issues or corporate issues seem to be greater. So though not a perfect measure, the spread on fixed interest rate swap contracts can be used as an indicator of the exchange rate determinant of the yield spread on government bonds, as it seems to be the best indicator of this yield spread component ${ }^{5}$.

So we denominate:

$I_{i, 10}=10$-year Yield on sovereign bonds of country $i$

$\operatorname{IRS} S_{i, 10}=10$-year Interest Rate Swap rate of currency $i$

Where, considering that differences in tax-regimes were reduced to insignificant levels during the course of the 1990s:

$I_{i, 10}=f\left(D R_{i, 10, L i 10,} E R_{i, 10}\right)$

$D R_{i, 10}=$ Default risk of country $i 10$-year sovereign bonds.

$L_{i, 10}=$ Liquidity of country $i 10$-year sovereign bonds.

$E R_{i, 10}=$ Exchange rate risk of currency $i$ over a 10-year horizon.

Therefore the 10-year yield differential of country $i$ over Germany will be:

YIELDSPRE $A D_{i l}=\left[I_{i, 10}-I_{G E, 10]_{t}}=f\left(\left[D R_{i ; 10}-D R_{G E, 10}\right]_{t,}\left[L_{i, 10}-L_{G E, 10}\right]_{t,}\left[E R_{i, 10}-E R_{G E, 10]_{t}}\right)\right.\right.$

Then, if we approximate:

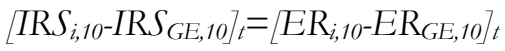

We can build up the variable "ADJUSTED SPREAD ${ }_{i t}$ ", as the difference between the total yield differential and the swap rate differential,

ADJUSTED SPRE $A D_{i t} \quad=A S P R E A D_{i t}=$

$$
\begin{gathered}
=\left[I_{i, 10}-I_{G E, 10]_{t}}-\left[\operatorname{IR} S_{i, 10}-I R S_{G E, 10]_{t}}=\right.\right. \\
=f\left(\left[D R_{i, 10}-D R_{G E, 10]_{t}}\left[L_{i, 10}-L_{G E, 10]_{t},}\left[E R_{i, 10}-E R_{G E, 10]_{t}}\right)-\left[E R_{i, 10}-E R_{G E, 10]_{t}}\right.\right.\right.\right.
\end{gathered}
$$

it can be inferred that the variable $A S P R E A D_{i t}$, which will be used as the dependent variable in the case of non-EMU countries, will mainly account for credit risk and market liquidity differences ${ }^{6}$ of

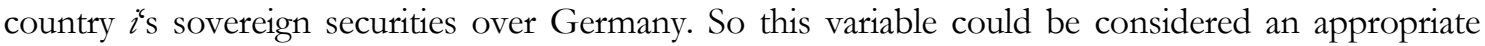

\footnotetext{
${ }^{5}$ See Gómez-Puig (2008a) for a much more detailed explanation.

${ }^{6}$ We are not considering the effect of international risk factors in this breakdown
} 
indicator of yield differential components not related to exchange rate factors. Table 4 presents the difference of 10-year spreads over Germany, in the three countries mentioned, when they are corrected from the exchange rate factor. As figure 6 shows, in the case of Sweden and the United Kingdom, their average is negative during the seven-year period.

\section{Data and explanatory variables.}

The sample includes all EU-15 countries, with the exception of Luxembourg and Greece. So, in this paper, we will expand on the analysis presented in Gómez-Puig (2008a and 2008b), where we studied the immediate effect of the introduction of a common currency on the risk factors that drive the evolution of yield spreads in both groups of countries. We will then use daily data spanning the period January 1, 1999 to December 31, 2005 which will enable us to analyse yield spreads behaviour of all EU-15 countries with the perspective given by this long period of time (seven years) since the beginning of Monetary Union.

The dependent variable used in our estimations is the spread (or adjusted spread) of 10-year government yield over Germany. Therefore, a crucial issue in this paper (and one that is vital for policymaking) is the identification of the two main local or domestic sources of risk that have made up yield spreads in European countries since the start of Monetary Integration. So, we attempt to break down the liquidity premium and credit-risk components by modeling their behavior to a number of factors that can potentially affect only one of them. With this goal in mind, the relative debt-to-GDP ratio will be used as a proxy to measure differences in credit risk ${ }^{7}$. This variable has been widely used in the literature by other authors (Bayoumi, Goldstein and Woglom (1995) among them $\left.^{8}\right)$ and, compared with other measures such as the rating differential, presents the advantage that it cannot be considered an ex-post measure of fiscal sustainability. Considering that a liquid market can be defined as one in which participants can rapidly execute a large volume of

\footnotetext{
7 Table 5 presents the outstanding amounts of government's securities at the end of each year of the sample. If we consider the EU-15 as a whole, the biggest markets, in descending order: the Italian, the German, the French, the British and the Spanish.

8 In particular, these authors find support for the market discipline hypothesis in the U.S. bond markets. This hypothesis assumes that yields rise smoothly at an increasing rate with the level of borrowing. However, if these incentives prove ineffective, credit markets will eventually respond by denying irresponsible borrowers further access to credit. Nevertheless, the model presented in this paper and Bayoumi et al. model do not control for the same variables and cannot be compared.
} 
transactions with a small impact on prices, in this paper, two different proxy variables will be used to measure this effect: (i) the bid/ask spread and (ii) the on-the run/off-the run spread. The bid/ask spread is one of the best measures of liquidity because it reflects the cost incurred by a typical investor in unwinding an asset position and measures one of the most important dimensions of liquidity: tightness, i.e. how far transaction prices differ from mid-market prices. Additionally, the liquidity of an asset is generally understood as the ease of its conversion into money. Therefore, because the conversion of an asset into money involves certain costs (search costs, delays, broker's commissions, etc...); the higher these costs, the lower the degree of liquidity. Note that as market dealers reduce their liquidity risk, the bid/ask spread should narrow with trading activity. Nevertheless, we will also include in our model a secondary measure of liquidity: the yield spread between more and less liquid securities, which is also a liquidity measure used in the Treasury market (see Fleming, 2003). Since liquidity has value, more liquid securities tend to have higher prices (lower yields) than less liquid securities. The yield spread is often calculated as the difference between the yield of an off-the-run (older securities of a given maturity) and that of an on-the-run (benchmark) security with similar cash-flow characteristics. Positive spreads indicate that on-therun securities are trading at a yield discount (or price premium) to off-the-run securities. Lastly, as noted above, a third point that will be assessed in this paper is the influence of international risk factors on yield spreads. Hence, the analysis will also build on the findings of recent works that suggest that yield spreads on government securities are sensitive to international risk factors, and compare the relative importance of these two sources (domestic and international) of risk factors on yield spreads.

Yields and swap rates were obtained from Datastream and correspond to the "on the run" (benchmark) 10-year issue for each market at every moment of time. They are quoted rates at market close. Datastream creates continuous yield series by taking the yield from the current benchmark in each market and using it to update a separate time series. As a benchmark changes, data are taken from a new stock on the first day of the month. Table 6 presents the starting benchmark dates used by Datastream as well as the characteristics of the different benchmarks that compose the yield series for the different countries of our sample. With regard to the bid/ask spreads series, daily time-series 
were created by calculating the spread between the bid and ask quotations provided by Bloomberg for the "on the run" (benchmark) 10-year issue for each market at every moment in time, using the same benchmarks and starting dates that Datastream uses to create the 10-year yield series. For all the different issues Bloomberg provides daily quoted prices calculated as the average bid and ask quotations at the close. A similar methodology is used to build the on-the-run/off-the-run spread daily time-series. These series were created by calculating the differences between the "on the run" (benchmark) 10-year issue and the "off the run" (immediately older security) 10-year issue yields provided by Bloomberg for each market at every moment of time, also using the same benchmarks and starting dates that Datastream uses to create the 10-year yield and swap rates series (see table 6). The overall outstanding amounts of public debt data have been drawn from the Bank for International Settlements (BIS; see table 5) and the GDP from Eurostat. However, as these series are only provided every three months, for the construction of the relative debt-to-GDP ratio daily timeseries, the rest of the data have been extrapolated assuming a daily constant rate of increase of those volumes, which in fact present very slight differences within countries over the studied period. For this reason, it can be assumed that the extrapolation will not produce important biases in the data and can be applied in this case. And finally, the spread between 10-year fixed interest rates on US swaps and the yield on 10-year Moody's Seasoned AAA US corporate bonds (USSPREAD ${ }^{i t}$ ), has been calculated from daily data obtained from Datastream. All the variables included in the estimation that capture domestic risk factors are relative to the German ones. Thus, BIDASKDIF it is the difference between the bid/ask spread in country $i$ and the bid/ask spread in Germany, ONOFFDIF it is the difference between the on the run /off the run spread in country $i$ and that in Germany and LNDEBTGDP ${ }_{i t}$ is the (log) deviation of country $i$ debt-to-GDP ratio from Germany's debt-to-GDP ratio.

\section{Model.}

In the specification, in addition to the local and world risk variables mentioned (LNDEBTGDP $P_{\text {it }}$ $B I D A S K D I F_{i t}, O N O F F D I F_{i t}$ and USSPREAD ${ }_{i t}$, country and monthly dummy variables will be introduced. Further, in order to assess whether there exists a varying relationship between liquidity 
variables and the yield $S P R E A D S_{i t}$ or $A S P R E A D S_{i t}$ (if liquidity is self-fulfilling, the proxies of market liquidity might present a non-linear relationship, i.e. a liquid/illiquid market might lead to an increasingly lower/higher liquidity premium) a quadratic specification for the variables $B I D A S K D I F_{i b}$ and $O N O F F D I F_{i t}$ is formulated.

So, with the following defined previously:

$B I D A S K D I F 2_{i t}=(B I D A S K D I F)^{2}$

ONOFFDIF $2_{i t}=(\mathrm{ONOFFDIF})^{2}$

The local risk variables $\left(Z_{i, t}\right)$ will be:

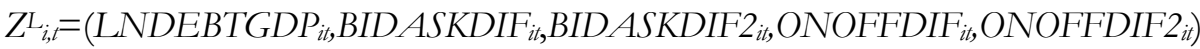

While the world risk variables $\left(Z^{W}{ }_{i, t}\right)$ will be:

$Z^{W_{i, t}}=U S S P R E A D_{i t}$

We first estimate model I, which is a panel model, in order to analyse whether there exist important differences in the effect of the different sources of risk on yield differentials in the two group of countries (euro and non-euro participating), then we allow for slope heterogeneity by estimating in model II a specific regression for each of the twelve countries in the sample.

Then, model I is a static panel regression ${ }^{9}$ with both domestic and international risk variables that will be estimated for both group of countries (EMU and non-EMU participating)

$y_{i t}=\alpha_{i}+\beta X_{i t}+\delta M O N T H L Y D U M M I E S_{t}+\lambda C O U N T R Y D U M M I E S_{i}+\varepsilon_{i t}$

Where, with the world $\left(Z^{W}{ }_{i, t}\right)$ and local risk variables $\left(Z^{L_{i, t}}\right)$ previously defined,

The vector of independent variables will be:

$X_{i t}=\left(Z^{W}{ }_{i, t}, Z^{L_{i, t}}\left[Z^{W}{ }_{i, t} \cdot Z^{L_{i, t}}\right)\right.$

In the above panel regressions, with very few exceptions, country dummies turn out to be significant at the 5 per cent confidence level, meaning that specific factors in each different country are relevant and suggesting that a separate estimation for each of them will provide fuller information. We will do

\footnotetext{
9 In Gómez-Puig (2008a), taking into account that some aspects of both domestic and international risk do not change over the considered period, with the objective to identify the relative importance of risk variables in explaining fluctuations, rather than levels of yield differentials, a lag of the dependent variable was introduced in the model. However, the results from both specifications (static and dynamic) only presented slight differences. This is the reason why we only estimate a static model in this paper.
} 
this in the second set of regressions (model II) where, using the same independent variables as in the panel regressions, a static regression will be implemented separately for each of the twelve countries in the sample. Therefore, the following empirical model on daily data will be implemented separately for each individual country ${ }^{10}$ :

$y_{i t}=\alpha_{\imath}+\beta X_{i t}+\delta M O N T H L Y D U M M I E S_{t}+\varepsilon_{i t}$

Hence, twelve regressions will be calculated, where the vector of independent variables will be:

$X_{i l}=\left(Z^{W}{ }_{i, t}, Z^{L_{i, b}}\left[Z^{W} i, Z^{L} L_{i, t}\right)\right.$

Model I and II will be estimated for the whole period (1999-2005), and the three sub-periods into which we have broken it down and, for both groups of countries. Our intention is to analyse whether the impact of the different variables changes throughout the two samples and between them. The first sub-period spans 1999 to 2000, the second 2001 to 2002 and the third 2003 to 2005.

\section{Results}

The estimation methods used in all specifications, Feasible Generalized Least Squares (FGLS) ${ }^{11}$ in the panel estimation and a regression with Newey-West standard errors in the estimations for each Euro-country, are robust to the possible existence of autocorrelation and heteroscedasticity in the error terms. Tables 7 and 8 present the results for EMU-countries. The panel regressions (table 7) clearly show that domestic risk factors are much more significant than common or international risk factors in explaining yield spread behaviour in EMU countries during the first seven years of Monetary Union. Actually, the world risk variable is only positively significant at the $10 \%$ confidence level in the estimation corresponding to the whole period. With regard to the domestic risk factors, the results show the following conclusions. Both credit risk (when it is interacted with

\footnotetext{
10 As it has been explained, in order to analyse whether it exist important differences in the effect of the different sources of risk in yield differentials in the two group of countries (euro and non-euro participating). In specification I, we implicitly impose the slope homogeneity assumption. This is the reason why we also include specification II where we allow a different slope for each country.

11 FGLS is only used in order to deal with the problem of possible existence of heterocedasticity or autocorrelation of the error term. This method of estimation allows to avoid this problem and to obtain robust results even when we impose the assumption of fixed effects in a panel model as it is imposed in our model.
} 
the international risk variable ${ }^{12}$ ) and liquidity risk (this one captured by the bid-ask spread) are the variables with higher impact on yield spreads. Both variables are positively significant at the $5 \%$ confidence level not only in the whole sample, but also in the three sub-periods. The self-fulfilling nature of liquidity is corroborated by the results. If we consider the coefficients of the quadratic liquidity variables interacted with the world risk variable, we can conclude that both the bid-ask spread and the on-the-run/off-the-run spread present a positive non-linear behavior (except in the period 1999-2000). Consequently, liquidity will be "self-reinforcing": since traders prefer to participate in liquid markets, more will participate in them, and the more liquid they will be. Finally, country dummy variables turn out to be always significant, with very few exceptions (France and the Netherlands in the estimation that includes the entire period, and Belgium in the first and second sub-periods). These results mean that specific factors in each different country are relevant and suggest that a separate estimation for each of them will provide wider information. This is why we estimate nine individual regressions for each country, using the same periods and the same explanatory variables as in the panel regressions. From these sets of estimations (tables 8) the following conclusions are worth noting. In the majority of the countries, the world risk factor only plays a marginal role. Actually, only in the case of Italy and Portugal (as we noted in table 2, Portugal is the only country that presented a positive correlation between its 10 -year yield spread over Germany and the US banking risk factor), does the world risk factor present a positive coefficient at the $5 \%$ confidence level not only for the complete period but also for at least one of the sub-periods. With regard to the domestic risk variables, the credit risk variable, except in the case of Ireland is positively significant in most of the countries at least for one or two sub-periods. It is also important to note that the negative coefficient that this variable presents in the case of France and Italy (the two biggest debt markets relative to the German one, see table 5) has been positive since 2003 in the case of France, and since 2001 in the case of Italy. These results imply that the "Too-big-to-fail" theory that we claimed in our earlier papers, where the sample finished in December 2001 (see Gómez-Puig 2008a and 2008b), may only be valid in the years immediately

\footnotetext{
12 The interaction term turns out to be significant in most of the cases, which supports the idea that it should be included in the estimations in order to avoid the omitted variables problem.
} 
after the beginning of the Monetary Union. Therefore, with a longer time perspective, agents seem to believe in the "no-bail-out" clause imposed by the EMU, even in the case of large debt markets. With regard to the liquidity variables, the linear and the non-linear behaviour of both the on-therun/off-the-run spread and the bid-ask spread is supported by the results (at least in most of the countries and sub-periods studied). Tables 9 and 10 present the results for non-EMU countries. In particular, table 9 displays the results of the panel estimation for the four periods. The most important conclusion that can be drawn from these results is that non-EMU countries present a greater vulnerability to world risk factors than EMU-countries ${ }^{13}$. In particular, the coefficient of the international risk factor is always positively significant at the $5 \%$ confidence level except for the period 2001-2002. The fact that these countries do not share a common Monetary Policy might explain their greater vulnerability to external risk factors. The results shown in table 9 also corroborate the importance of domestic risk factors (both liquidity and credit risk) in yield spread behaviour. Moreover, the non-linear behaviour presented by liquidity proxies supports the selffulfilling nature of liquidity. Finally, table 10 presents the results for each of the three countries in this second group. Note that whilst panel regression supported the relevance of systemic risk in adjusted spread behaviour, the significance of the variable that captures this effect disappears in country-specific estimations. In these sets of estimations, it is domestic variables, and especially liquidity risk variables (both in their linear and non-linear form) that mostly drive adjusted spread behaviour.

\section{Conclusions}

In this paper we have implemented a panel regression both for the whole period (1999-2005) and for the three sub-periods into which these seven years have been broken down, and an individual regression (with the same explanatory variables as in the panel regressions) for the nine and three countries in the two groups (EMU participants and EMU non-participants respectively). Specific-

\footnotetext{
13 Dewatcher et al. (2004) find that after Monetary Unification observed German bond yields are significantly lower than they would have been under Bundesbank policy and Allen and Song (2005) present some evidence that EMU has helped financial integration within the euro area.
} 
country regressions are estimated for the same four periods as in the panel regressions. The results present clear evidence that it is domestic rather than international risk factors that mostly drive the evolution of 10-year yield spread differentials over Germany in all EMU countries during the seven years after the beginning of Monetary Integration. These results appear to be sound if we bear in mind that common factors (captured by world risk factors) will disappear when we take differentials between bond yields that present a very high correlation ( 0.99 on average). Therefore, even though bond returns present a high co-movement (systemic risk accounts for a large proportion of their behavior), a very substantial part of this movement cancels out if we study yield spreads, which mostly reflect idiosyncratic/local or domestic risk, i.e. specific factors in each different country. In the case of non-EMU countries, where 10-year government yields do not display such high co-movement (see figure 3), adjusted yield spreads (corrected from the foreign exchange factor) are influenced more by world risk factors. The fact that these countries do not share a common Monetary Policy might explain these results. In addition, outside the Monetary Union, these debt markets did not suffer the increase in their degree of substitutability and competition experienced by EMU-debt markets since January 1999. So this situation has benefited them (mainly in the first years after the beginning of Monetary Union), insofar as market participants consider their risk premium to be low and the investment advantages to be high. Finally, the results also support the relevance of domestic risk factors (especially market liquidity differences, which influence yield spreads both in a linear and in a non-linear way) in adjusted spread behavior in non-EMU participating countries. 


\section{References}

1. Adjaouté, K, L. Bottazi, J.P. Danthine, A. Fischer, R. Hamaui, R. Portes and M. Wickens (2000). "EMU and Portfolio Adjustment". CEPR Policy Paper N5.

2. Allen, F. and W.L. Song (2005). "Financial Integration and EMU". European Financial Management Vol. 11, No. 1, pp. 7-24.

3. Barassi, M. R., Caporale, G. M. and Hall, S. G. (2001). "Irreducibility and structural cointegrating relations: An application to the G-7 long-term interest rates". International Journal of Finance and Economics n.6, pp.127-38.

4. Bessler, D.A. and J. Yang (2003). "The structure of interdependence in international stock markets". Journal of International Money and Finance n.23, pp.71-97.

5. Bayoumi, T. M. Goldstein and G. Woglom (1995). "Do Credit Markets Discipline Sovereign Borrowers? Evidence from the US States". Journal of Money Credit and Banking 27 (4) pp.10461059.

6. Barr, D.G. and R. Priestley. (2004). "Expected returns, risk and the integration of international bond markets". Journal of International Money and Finance n. 23.

7. Bekaert, G, and C.R. Harvey (1995). “Time-Varying World Market Integration". Journal of Finance vol. 1, n.2.

8. Bekaert, G, and C.R. Harvey (1997). "Emerging equity market volatility". Journal of Finance, 50, 403.

9. Bekaert, G, C.R. Harvey and A. Ng (2005). "Market Integration and Contagion". Journal of Business, vol. 78. n.1.

10. Calvo, G.A. and C.M. Reinhart (1996). "Capital flows to Latin America: Is there evidence of contagion effects. In G. Calvo, M. Goldstein and E. Hochreiter (Eds). Private capital flows to emerging markets. Institute of International Economics (Washington).

11. Christiansen, C. (2007). "Volatility Spillover Effects in European Bond Markets". European Financial Management, Vol. 13, No. 5, pp. 923-948.

12. Cifarelli, G. and G. Paladino (2006). "Volatility co-movements between emerging sovereign bonds: Is there segmentation between geographical areas? Global Finance Journal n. 16. 
13. Clare, A., Maras, M. and Thomas, S. (1995). "The integration and efficiency of international bond markets", Journal of Business Finance and Accounting, 22, 313-22.

14. Cox, J.C.; J. Ingersoll and S.A. Ross (1985). "A theory of the term structure of interest rates". Econometrica, n. 53 (2), pp.385-407.

15. DeGennaro, R., R. Kunkel, R. and J, Lee (1994). "Modeling international long-term interest rates". Financial Review n.29, pp. 577-97.

16. Dewatcher, H., M. Lyrio and K. Maes (2004). “The Effect of Monetary Unification on German Bond Markets". European Financial Management, Vol. 10, No. 3, pp. 487-509.

17. Driessen, J., Melenberg, B. and Nijman, T. (2003). "Common Factors in International Bond Returns". Journal of International Money and Finance 22(5), pp.629-656.

18. Dumas, B. and B. Solnik (1995). "The world price of foreign exchange risk". Journal of Finance $n$. 50, pp.445-479.

19. Economides, N. and A. Siow (1988). "The Division of Markets is Limited by the Extent of Liquidity (Spatial Competition with Externalities)". American Economic Review, Vol.78, $n^{\circ} 1$ pp 1719-1734.

20. Favero, C., F. Giavazzi and L. Spaventa (1997). High Yields: The Spread on German Interest Rate. The Economic Journal, Vol.107, Issue 443.

21. Favero, C. and F. Giavazzi (2002). "Is the International Propagation of Financial Shocks NonLinear? Evidence from the ERM". Journal of International Economics, 57 (1), pp.231-246.

22. Favero, C., M. Pagano and E.L. von Thadden. (2007). "How Does Liquidity Affect Government Bond Yields?”. Forthcoming in the Journal of Financial and Quantitative Analysis.

23. Fleming, M.J., (2003). "Measuring Treasury Market Liquidity". Federal Reserve Bank of New York. Economic Policy Review 9, pp.83-108.

24. Geyer, A., S. Kossmeier and S. Pichler (2004). "Measuring Systematic Risk in EMU Government Yield Spreads". Review of Finance n. 8.

25. Gómez-Puig, M., (2006). "Size Matters for Liquidity: Evidence from EMU sovereign yield spreads". Economics Letters, Vol.9, Issue 2; pp.156-162, February. 
26. Gómez-Puig, M. (2008a). "Monetary Integration and the Cost of Borrowing". Journal of International Money and Finance, Vol.27, Issue 3; pp. 455-479

27. Gómez-Puig, M. (2008b) “The Immediate Effect of Monetary Union over EU-15’s Sovereign Debt Yield Spreads", forthcoming in Applied Economics.

28. Hunter, D.M. and D.P. Simon (2005). “A Conditional Assessment of the Relationships between the Major World Bond Markets". European Financial Management Vol. 11, No. 4, pp. 463 482.

29. Ilmanen, A. (1995). "Time-Varying Expected Returns in International Bond Markets". The Journal of Finance vol. L. n.2.

30. Masson, P. (1999). "Contagion: Monsoonal effects, spillovers and jumps between multiple equilibria”, in AGenor, P.R., M. Miller, D. Vines and D.Weber (eds), The Asian Financial Crisis: Causes, Contagion and Consequences, Cambridge University Press, Cambridge.

31. Pagano, M. and E.L. von Thadden. (2004). "The European Bond Markets under EMU”. Oxford Review of Economic Policy, vol. 20, n.4.

32. Pesaran, M.H. and A.Pick (2007). "Econometric issues in the analysis of contagion". Journal of Economic Dynamics \& Control n31, pp.1245-1277.

33. Smith, K.L.(2002). "Government bond market seasonality, diversification, and cointegration: international evidence". Journal of Financial Research, n. 25, pp.203-221.

34. Tesar, L. and I. Werner, 1995. Home bias and high turnover. Journal of International Money and Finance, Vol.14, Nº 4, pp.467-492. 


\section{Figure 1}

EMU Countries' 10 year yields

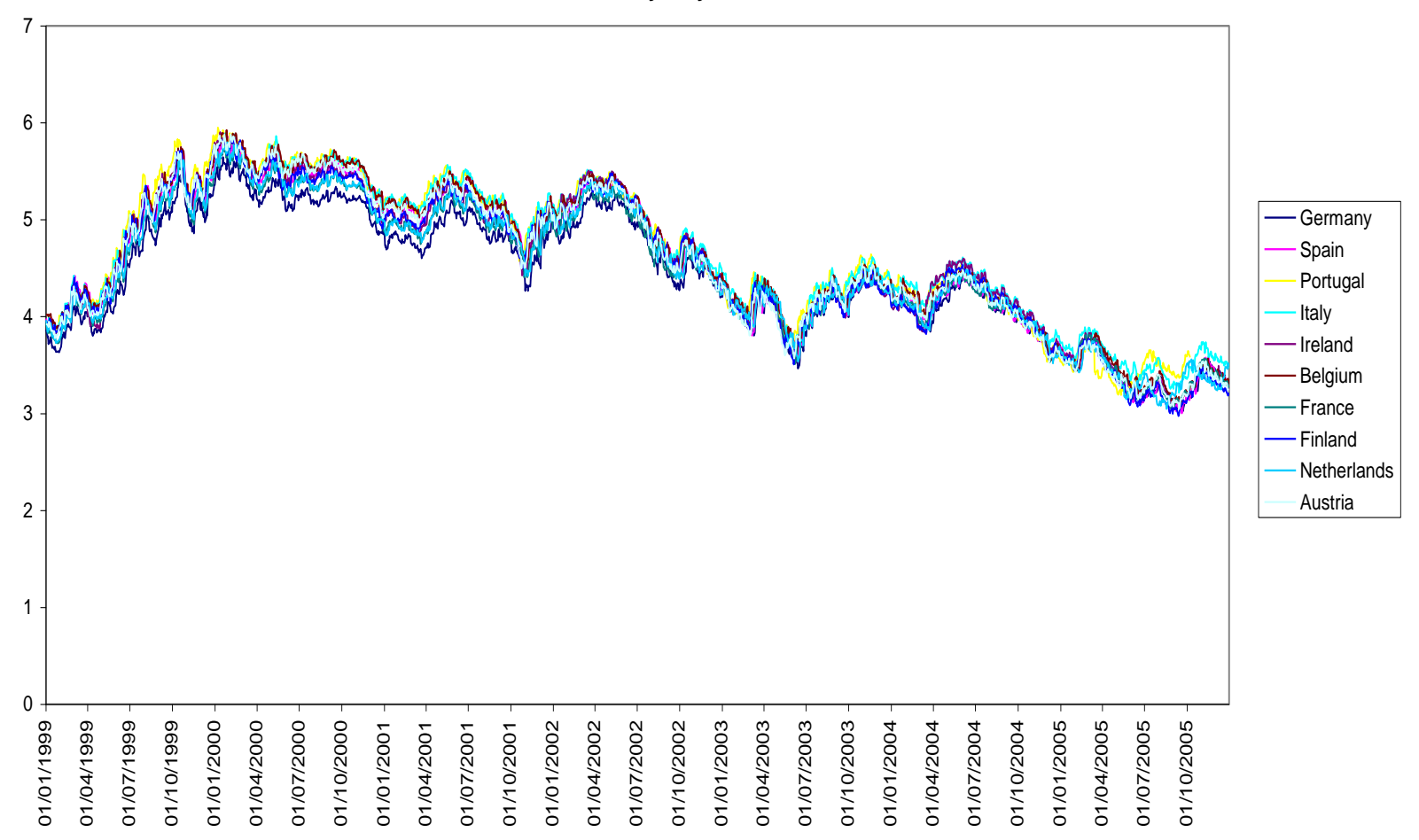

Source: Datastream

Figure 2

EMU Countries' 10-year spread over Germany

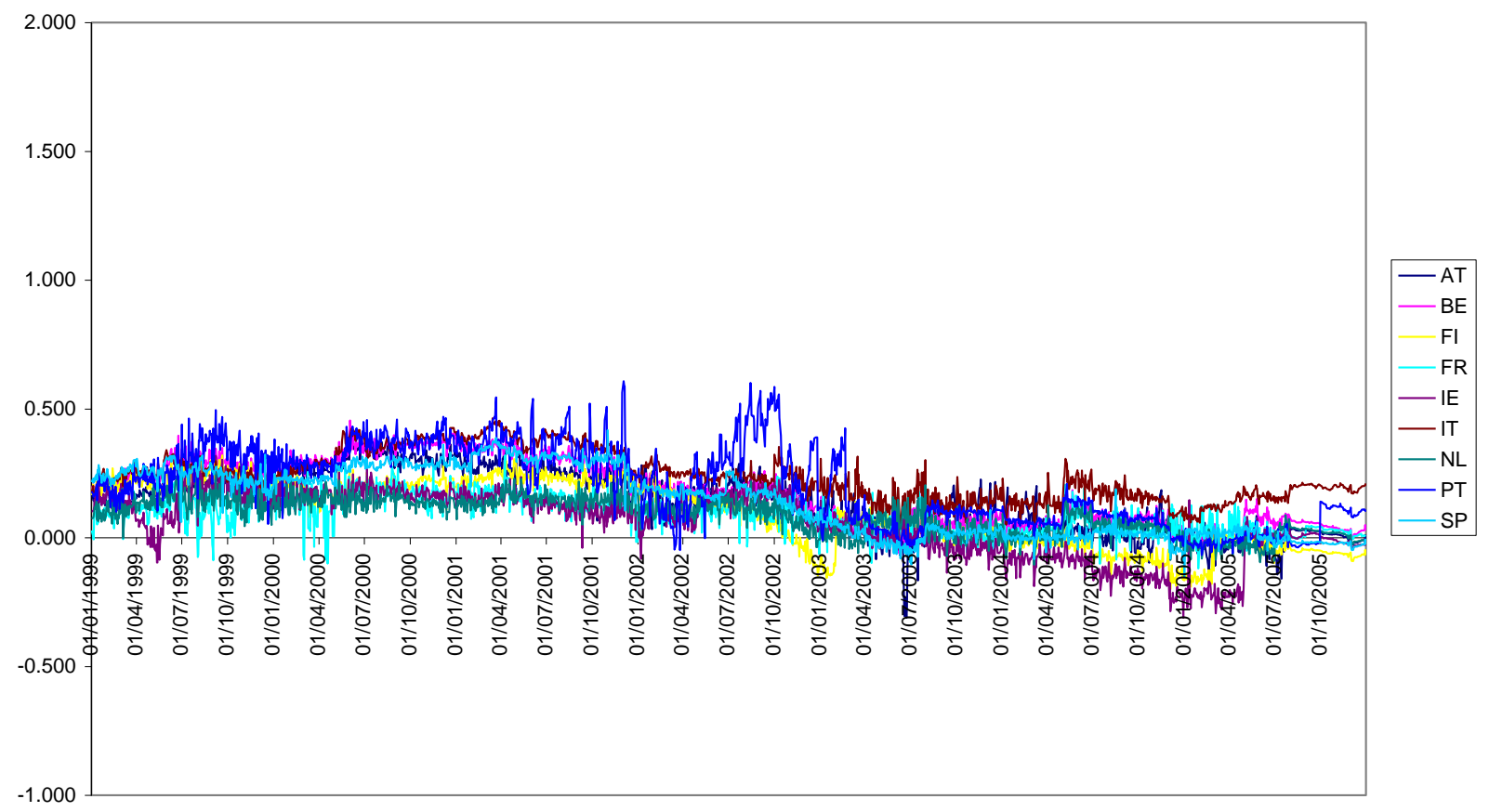

NOTE: AT: Austria, BE: Belgium, FI: Finland, FR: France, IE: Ireland, IT: Italy, NL: The Netherlands, PT:

Portugal, SP: Spain. Source: Datastream 
Figure 3

10-year Government's yields

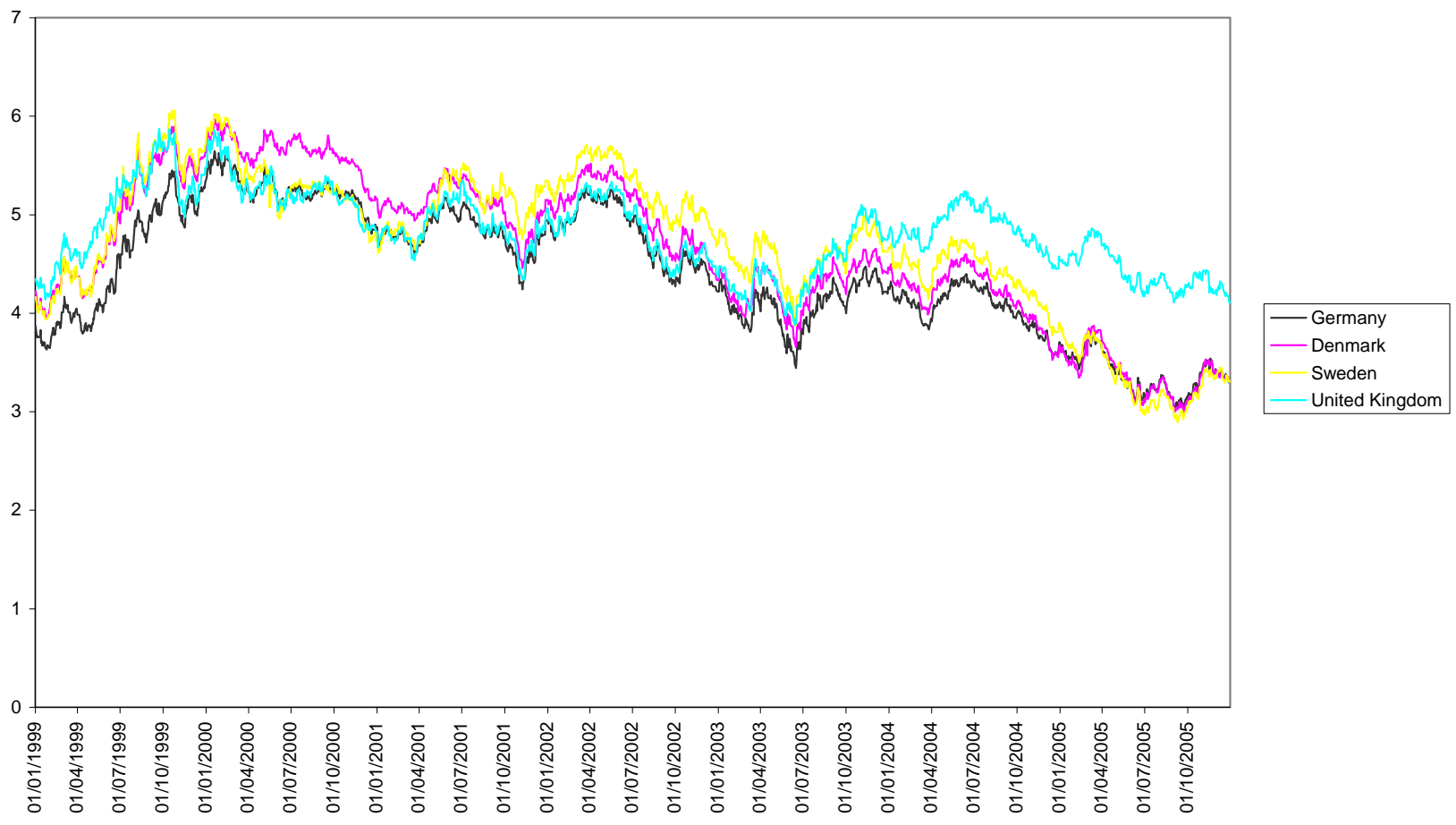

Source: Datastream

Figure 4

10-year yield spread over Germany

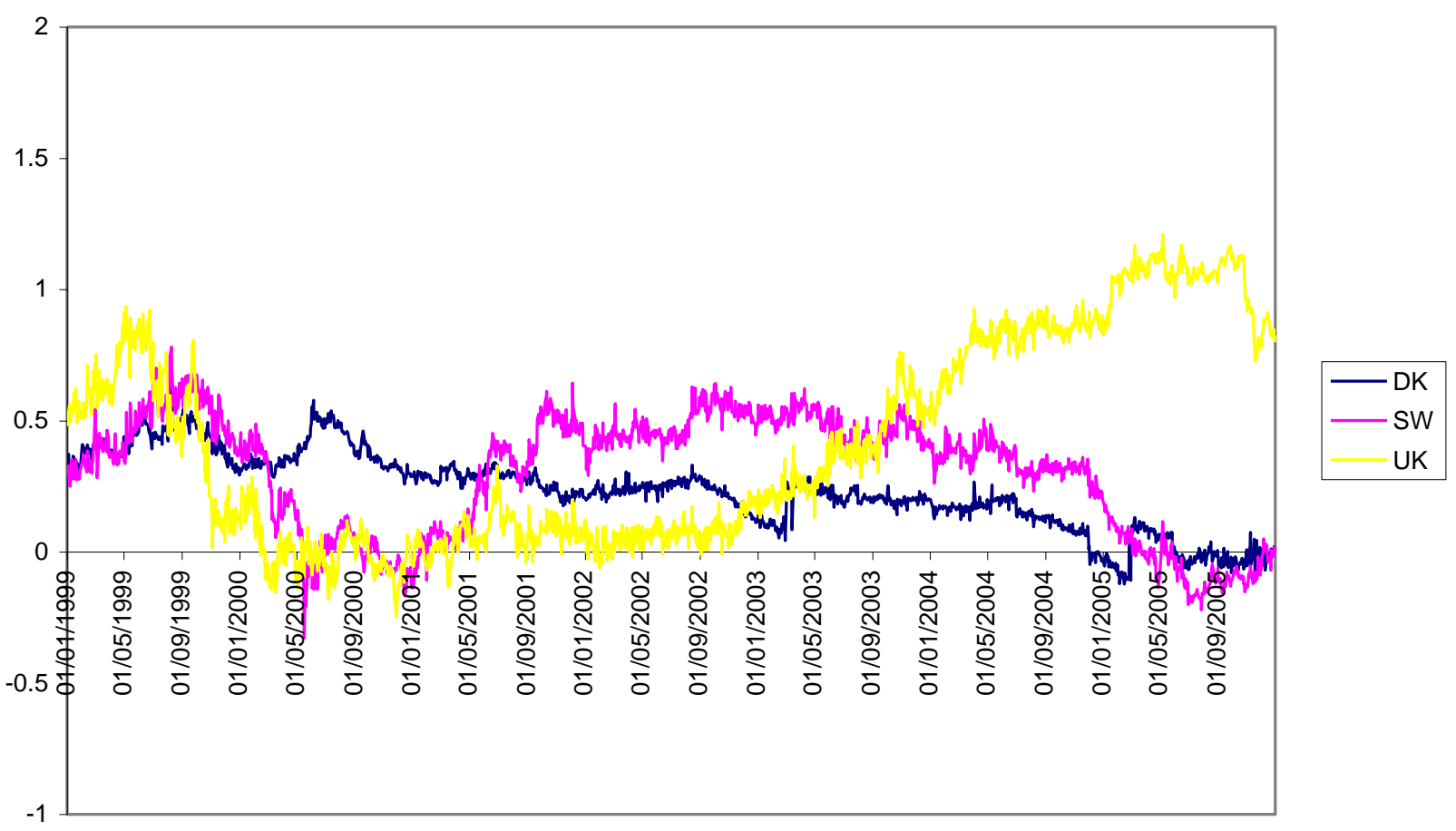

NOTE: DK: Denmark, SW: Sweden and UK: the United Kingdom. Source: Datastream 
Figure 5

10-year swap spreads over Germany

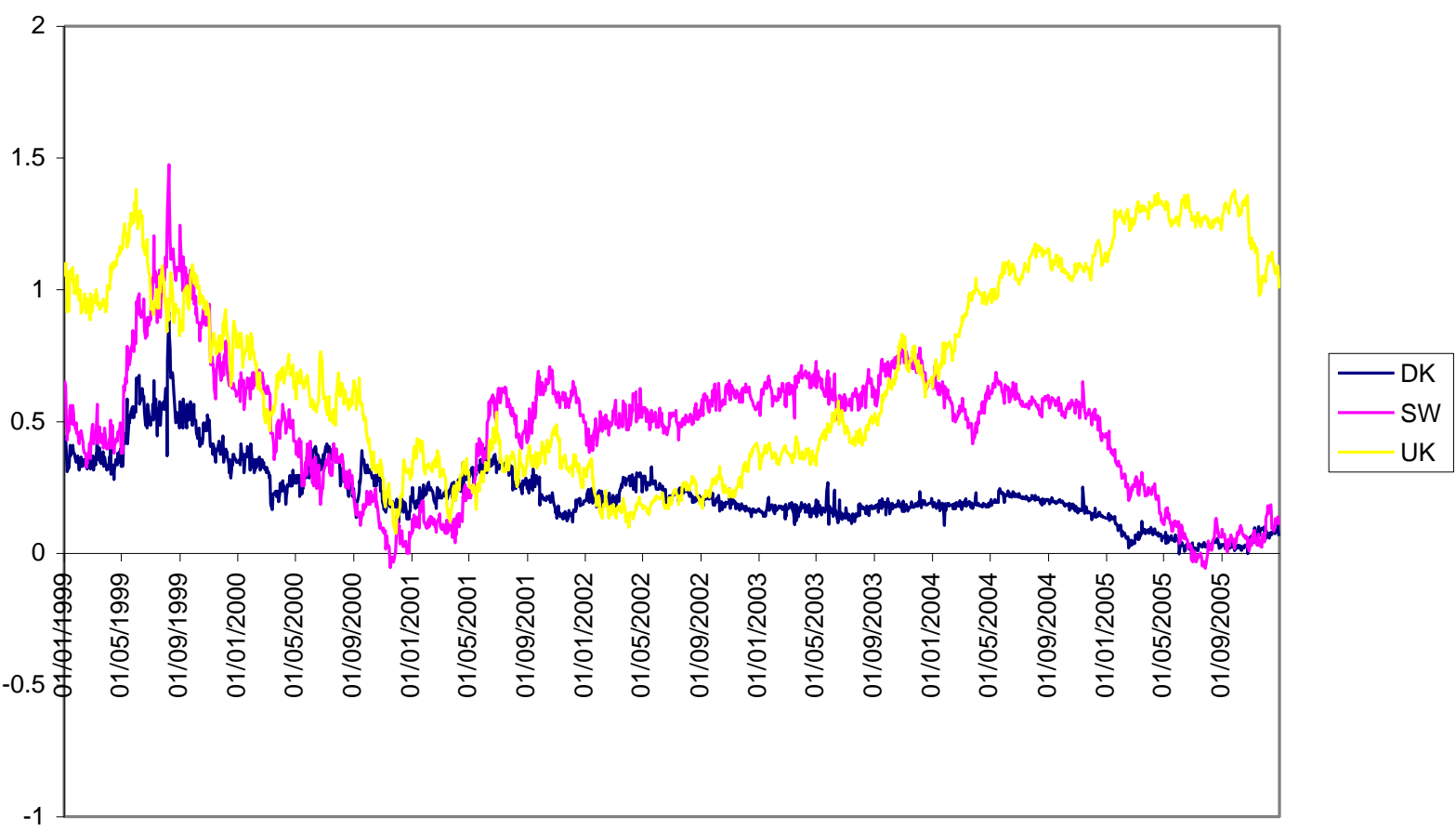

NOTE: DK: Denmark, SW: Sweden and UK: the United Kingdom. Source: Datastream

Figure 6

10-year adjusted spreads over Germany

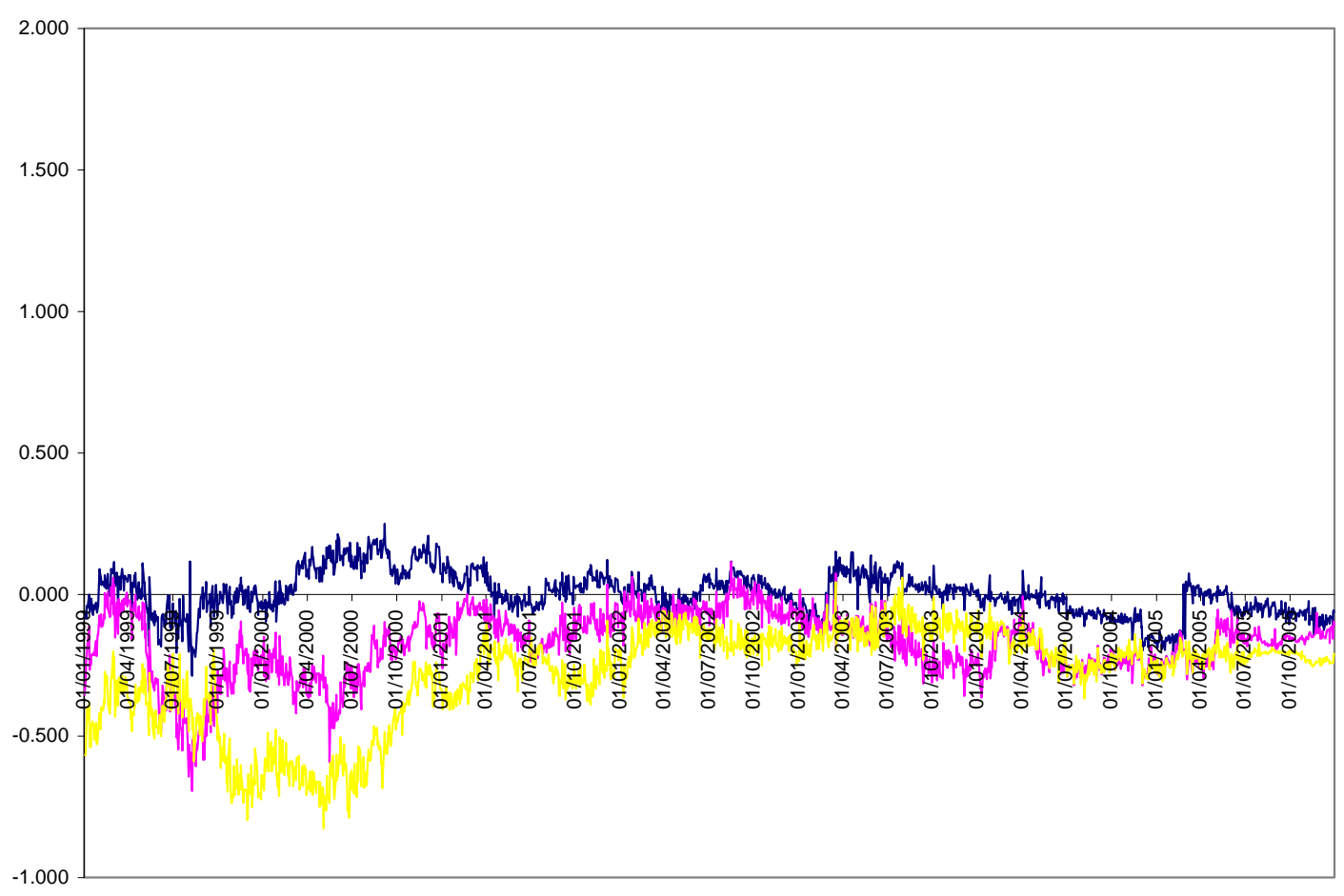

Source: Datastream. 
Table 1- Correlation coefficient: 10-year government yields in the EU-15 and US (1999-2005)

\begin{tabular}{|c|c|c|c|c|c|c|c|c|c|c|c|c|c|c|}
\hline & US & GE & AT & BE & FI & FR & IE & IT & NL & PT & SP & DK & SW & UK \\
\hline US & 1.000 & & & & & & & & & & & & & \\
\hline GE & 0.743 & 1.000 & & & & & & & & & & & & \\
\hline AT & 0.757 & 0.996 & 1.000 & & & & & & & & & & & \\
\hline BE & 0.769 & 0.994 & 0.997 & 1.000 & & & & & & & & & & \\
\hline FI & 0.768 & 0.993 & 0.994 & 0.997 & 1.000 & & & & & & & & & \\
\hline FR & 0.751 & 0.997 & 0.996 & 0.996 & 0.994 & 1.000 & & & & & & & & \\
\hline IE & 0.754 & 0.992 & 0.994 & 0.995 & 0.994 & 0.993 & 1.000 & & & & & & & \\
\hline IT & 0.757 & 0.995 & 0.997 & 0.998 & 0.995 & 0.997 & 0.994 & 1.000 & & & & & & \\
\hline NL & 0.754 & 0.998 & 0.996 & 0.997 & 0.996 & 0.997 & 0.995 & 0.997 & 1.000 & & & & & \\
\hline PT & 0.744 & 0.990 & 0.994 & 0.994 & 0.990 & 0.992 & 0.993 & 0.994 & 0.992 & 1.000 & & & & \\
\hline SP & 0.766 & 0.993 & 0.997 & 0.998 & 0.997 & 0.995 & 0.994 & 0.997 & 0.996 & 0.993 & 1.000 & & & \\
\hline DK & 0.765 & 0.992 & 0.992 & 0.993 & 0.995 & 0.992 & 0.991 & 0.990 & 0.994 & 0.988 & 0.993 & 1.000 & & \\
\hline SW & 0.622 & 0.955 & 0.943 & 0.940 & 0.948 & 0.948 & 0.946 & 0.937 & 0.954 & 0.943 & 0.942 & 0.957 & 1.000 & \\
\hline UK & 0.793 & 0.836 & 0.820 & 0.825 & 0.821 & 0.826 & 0.803 & 0.817 & 0.833 & 0.805 & 0.820 & 0.834 & 0.797 & 1.000 \\
\hline
\end{tabular}

NOTE: US: The United States, GE: Germany, AT: Austria, BE: Belgium, FI: Finland, FR: France, IE: Ireland, IT: Italy, NL: The Netherlands, PT: Portugal, SP: Spain, DK: Denmark, SW: Sweden and UK: The United Kingdom. Source: Datastream

Table 2- Correlation coefficient: EU-15 spreads/aspreads over 10-year Germany government yields and US risk factor (1999-2005)

\begin{tabular}{|c|c|}
\hline & US \\
\hline US & 1.000 \\
\hline AT & -0.056 \\
\hline BE & -0.136 \\
\hline FI & -0.113 \\
\hline FR & -0.026 \\
\hline IE & -0.004 \\
\hline IT & -0.017 \\
\hline NL & -0.055 \\
\hline PT & 0.107 \\
\hline SP & -0.052 \\
\hline DK & 0.088 \\
\hline SW & 0.546 \\
\hline UK & 0.556 \\
\hline
\end{tabular}

NOTE: US: The United States, AT: Austria, BE: Belgium, FI: Finland, FR: France, IE: Ireland, IT: Italy, NL: The Netherlands, PT: Portugal, SP: Spain, DK: Denmark, SW: Sweden, UK: The United Kingdom. Source: Datastream 
Table 3- 10-year yield spreads/aspreads over Germany (1999-2005)

\begin{tabular}{|c|c|c|c|c|c|}
\hline \multicolumn{6}{|c|}{ 10 year yield spread/adjusted spread over Germany } \\
\hline \multirow{2}{*}{ AT } & average & 1P: 1999-2000 & 2P: 2001-2002 & 3P: 2003-2005 & 1999-2005 \\
\cline { 2 - 6 } & st.deviation & 0.240 & 0.209 & 0.021 & 0.137 \\
\hline \multirow{2}{*}{ BE } & average & 0.295 & 0.067 & 0.062 & 0.120 \\
\cline { 2 - 6 } & st.deviation & 0.057 & 0.245 & 0.054 & 0.177 \\
\hline \multirow{2}{*}{ FI } & average & 0.214 & 0.165 & -0.042 & 0.124 \\
\cline { 2 - 6 } & st.deviation & 0.037 & 0.091 & 0.066 & 0.097 \\
\hline \multirow{2}{*}{ FR } & average & 0.136 & 0.122 & 0.033 & 0.128 \\
\cline { 2 - 6 } & st.deviation & 0.062 & 0.051 & 0.042 & 0.088 \\
\hline \multirow{2}{*}{ IE } & average & 0.156 & 0.128 & -0.065 & 0.053 \\
\cline { 2 - 6 } & st.deviation & 0.060 & 0.050 & 0.090 & 0.126 \\
\hline \multirow{2}{*}{ IT } & average & 0.298 & 0.309 & 0.156 & 0.240 \\
\cline { 2 - 6 } & st.deviation & 0.062 & 0.075 & 0.045 & 0.094 \\
\hline \multirow{2}{*}{ NL } & average & 0.139 & 0.125 & 0.022 & 0.085 \\
\cline { 2 - 6 } & st.deviation & 0.037 & 0.044 & 0.047 & 0.070 \\
\hline \multirow{2}{*}{ PT } & average & 0.307 & 0.306 & 0.062 & 0.202 \\
\cline { 2 - 6 } & st.deviation & 0.081 & 0.125 & 0.070 & 0.152 \\
\hline \multirow{2}{*}{ SP } & average & 0.256 & 0.235 & 0.004 & 0.142 \\
\cline { 2 - 6 } & st.deviation & 0.037 & 0.083 & 0.030 & 0.131 \\
\hline \multirow{2}{*}{ DK } & average & 0.034 & 0.020 & -0.029 & 0.003 \\
\cline { 2 - 6 } & st.deviation & 0.093 & 0.043 & 0.067 & 0.076 \\
\hline \multirow{2}{*}{ SW } & average & -0.254 & -0.084 & -0.186 & -0.176 \\
\cline { 2 - 6 } & st.deviation & 0.138 & 0.061 & 0.066 & 0.112 \\
\hline \multirow{2}{*}{ UK } & average & -0.496 & -0.213 & -0.183 & -0.281 \\
\cline { 2 - 6 } & st.deviation & 0.146 & 0.080 & 0.064 & 0.168 \\
\hline \multirow{2}{*}{} & & & & & \\
\hline
\end{tabular}

NOTE: AT: Austria, BE: Belgium, FI: Finland, FR: France, IE: Ireland, IT: Italy, NL: The Netherlands, PT: Portugal, SP: Spain, DK: Denmark, SW: Sweden, UK: The United Kingdom. Source: Datastream

Table 4

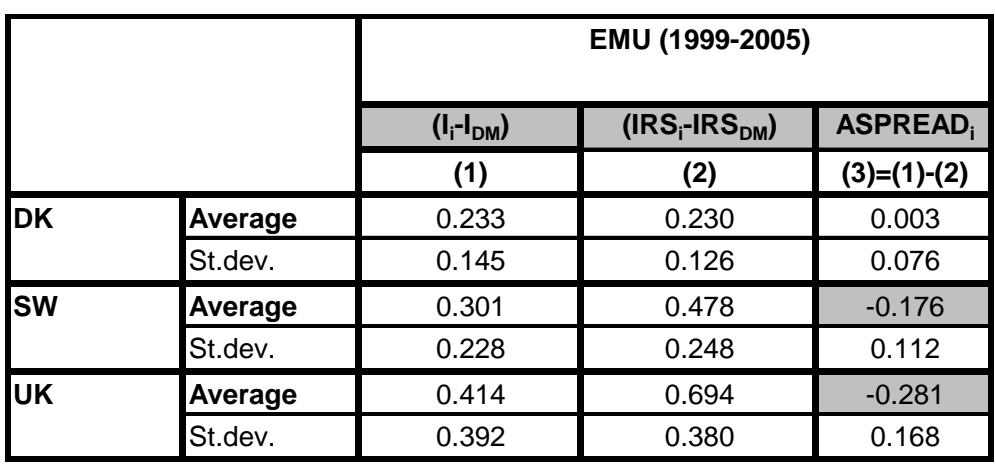

NOTE: DK: Denmark, SW: Sweden, UK: The United Kingdom. Source: Datastream 
Table 5

\begin{tabular}{|c|c|c|c|c|c|c|c|c|c|c|}
\hline \multicolumn{10}{|c|}{ OUTSTANDING AMOUNTS OF GOVERNMENT'S DEBT (billions of euros) } & \multirow[b]{2}{*}{ average $\%$ of EU-15 } \\
\hline & $1999-12$ & $2000-12$ & $2001-12$ & $2002-12$ & 2003-12 & $2004-12$ & $2005-12$ & average $99-05$ & average $\%$ of EMU & \\
\hline Austria & 75.35 & 81.03 & 83.40 & 83.25 & 78.41 & 77.60 & 80.1 & 79.9 & $2.19 \%$ & $1.88 \%$ \\
\hline Belgium & 233.82 & 238.90 & 247.93 & 252.50 & 252.54 & 250.13 & 256.9 & 247.5 & $6.78 \%$ & $5.84 \%$ \\
\hline Finland & 45.89 & 46.00 & 46.98 & 47.20 & 52.14 & 54.55 & 49.2 & 48.9 & $1.34 \%$ & $1.15 \%$ \\
\hline France & 603.72 & 639.98 & 676.16 & 732.14 & 817.7 & 862.93 & 910.6 & 749.0 & $20.52 \%$ & $17.67 \%$ \\
\hline Germany & 610.29 & 640.19 & 680.25 & 744.64 & 812.94 & 875.63 & 899.7 & 751.9 & $20.59 \%$ & $17.74 \%$ \\
\hline Greece & 88.99 & 93.28 & 103.48 & 123.20 & 138.81 & 158.95 & 175.9 & 126.1 & $3.45 \%$ & $2.97 \%$ \\
\hline Ireland & 24.89 & 23.21 & 20.20 & 22.69 & 28.33 & 31.35 & 31.7 & 26.1 & $0.71 \%$ & $0.61 \%$ \\
\hline Italy & 1041.21 & 1042.67 & 1063.43 & 1060.65 & 1074.6 & 1097.50 & 1156.2 & 1076.6 & $29.49 \%$ & $25.40 \%$ \\
\hline Netherlands & 180.87 & 176.36 & 179.73 & 188.23 & 203.41 & 214.82 & 227.35 & 195.8 & $5.36 \%$ & $4.62 \%$ \\
\hline Portugal & 37.73 & 40.84 & 46.18 & 56.74 & 62.62 & 70.85 & 82.8 & 56.8 & $1.56 \%$ & $1.34 \%$ \\
\hline Spain & 299.52 & 314.45 & 319.19 & 328.79 & 330.56 & 337.57 & 343.2 & 324.8 & $8.89 \%$ & $7.66 \%$ \\
\hline EMU & 3242.29 & 3336.92 & 3466.92 & 3640.03 & 3852.06 & 4031.86 & 3988.0 & 3651.2 & $100.00 \%$ & $86.14 \%$ \\
\hline Denmark & 92.08 & 88.88 & 88.28 & 93.07 & 83.65 & 84.58 & 77.2 & 86.8 & - & $2.05 \%$ \\
\hline Sweden & 123.83 & 113.06 & 92.36 & 99.27 & 112.54 & 117.25 & 109.8 & 109.7 & - & $2.59 \%$ \\
\hline United Kingdom & 459.88 & 458.36 & 466.58 & 452.01 & 466.31 & 602.58 & 680.41 & 512.30 & - & $12.09 \%$ \\
\hline non-EMU & 675.79 & 660.29 & 647.23 & 644.04 & 601.11 & 696.87 & 867.4 & 684.68 & - & $16.15 \%$ \\
\hline EU-15 & 3918.08 & 3997.21 & 4114.15 & 4284.07 & 4453.17 & 4728.73 & 4175.1 & 4238.64 & - & $100.00 \%$ \\
\hline United States & 4380.35 & 4408.28 & 4765.57 & 4329.74 & 3984.84 & 4059.10 & 4806.0 & 4390.56 & - & - \\
\hline
\end{tabular}

Source: Bank for International Settlements

Table 6

\begin{tabular}{|l|c|c|c|c|}
\hline & Issue Date & Symbol & Coupon & Maturity Date \\
\hline AUSTRIA & $01 / 02 / 1998$ & RAGB & $5 \%$ & $15 / 01 / 2008$ \\
\hline \multirow{5}{*}{} & $01 / 04 / 1999$ & RAGB & $4 \%$ & $15 / 07 / 2009$ \\
\cline { 2 - 5 } & $01 / 12 / 1999$ & RAGB & $5.50 \%$ & $15 / 01 / 2010$ \\
\cline { 2 - 5 } & $01 / 05 / 2001$ & RAGB & $5.25 \%$ & $04 / 01 / 2011$ \\
\cline { 2 - 5 } & $01 / 05 / 2002$ & RAGB & $5 \%$ & $15 / 07 / 2012$ \\
\cline { 2 - 5 } & $01 / 08 / 2003$ & RAGB & $3.80 \%$ & $20 / 10 / 2013$ \\
\cline { 2 - 5 } & $01 / 11 / 2004$ & RAGB & $4.30 \%$ & $15 / 07 / 2014$ \\
\cline { 2 - 5 } & $01 / 08 / 2005$ & RAGB & $3.50 \%$ & $25 / 10 / 2015$ \\
\hline \multirow{5}{*}{ BELGIUM } & $01 / 01 / 1997$ & BGB & $6.25 \%$ & $28 / 03 / 2007$ \\
\hline & $01 / 12 / 1997$ & BGB & $5.75 \%$ & $28 / 03 / 2008$ \\
\cline { 2 - 5 } & $01 / 02 / 1999$ & BGB & $3.75 \%$ & $28 / 03 / 2009$ \\
\cline { 2 - 5 } & $01 / 02 / 2000$ & BGB & $5.75 \%$ & $28 / 09 / 2010$ \\
\cline { 2 - 5 } & $01 / 05 / 2001$ & BGB & $5 \%$ & $28 / 09 / 2011$ \\
\cline { 2 - 5 } & $01 / 08 / 2002$ & BGB & $5 \%$ & $28 / 09 / 2012$ \\
\cline { 2 - 5 } & $01 / 07 / 2003$ & BGB & $4.25 \%$ & $28 / 09 / 2013$ \\
\cline { 2 - 5 } & $01 / 05 / 2004$ & BGB & $4.25 \%$ & $28 / 09 / 2014$ \\
\cline { 2 - 5 } & $01 / 05 / 2005$ & BGB & $3.75 \%$ & $28 / 09 / 2015$ \\
\hline FINLAND & $01 / 12 / 1998$ & RFGB & $5 \%$ & $25 / 04 / 2009$ \\
\hline & $01 / 02 / 2000$ & RFGB & $5.75 \%$ & $23 / 02 / 2011$ \\
\hline & $01 / 02 / 2001$ & RFGB & $5.75 \%$ & $23 / 02 / 2011$ \\
\hline & $01 / 02 / 2003$ & RFGB & $5.38 \%$ & $04 / 07 / 2013$ \\
\hline & $01 / 03 / 2005$ & RFGB & $4.25 \%$ & $04 / 07 / 2015$ \\
\hline
\end{tabular}


Table 6 (cont)

\begin{tabular}{|c|c|c|c|c|}
\hline & Issue Date & Symbol & Coupon & Maturity Date \\
\hline \multirow[t]{15}{*}{ FRANCE } & $01 / 01 / 1999$ & FRTR & $4 \%$ & $25 / 04 / 2009$ \\
\hline & $01 / 07 / 1999$ & FRTR & $4 \%$ & $25 / 10 / 2009$ \\
\hline & $01 / 03 / 2000$ & FRTR & $5.50 \%$ & $25 / 04 / 2010$ \\
\hline & $01 / 09 / 2000$ & FRTR & $5.50 \%$ & $25 / 10 / 2010$ \\
\hline & $01 / 06 / 2001$ & FRTR & $6.50 \%$ & $25 / 04 / 2011$ \\
\hline & $01 / 01 / 2002$ & FRTR & $5 \%$ & $25 / 10 / 2011$ \\
\hline & $01 / 05 / 2002$ & FRTR & $5 \%$ & $25 / 04 / 2012$ \\
\hline & $01 / 10 / 2002$ & FRTR & $4.75 \%$ & $25 / 10 / 2012$ \\
\hline & $01 / 04 / 2003$ & FRTR & $4 \%$ & $25 / 04 / 2013$ \\
\hline & $01 / 01 / 2004$ & FRTR & $4 \%$ & $25 / 10 / 2013$ \\
\hline & $01 / 05 / 2004$ & FRTR & $4 \%$ & $25 / 04 / 2014$ \\
\hline & $01 / 12 / 2004$ & FRTR & $4 \%$ & $25 / 10 / 2014$ \\
\hline & $01 / 05 / 2005$ & FRTR & $3.50 \%$ & $25 / 04 / 2015$ \\
\hline & $01 / 09 / 2005$ & FRTR & $3 \%$ & $25 / 10 / 2015$ \\
\hline & $01 / 03 / 2006$ & FRTR & $3.25 \%$ & $25 / 04 / 2016$ \\
\hline \multirow[t]{16}{*}{ GERMANY } & $01 / 08 / 1998$ & DBR & $43 / 4 \%$ & 04/07/2008 \\
\hline & $01 / 02 / 1999$ & DBR & $33 / 4 \%$ & 04/01/2009 \\
\hline & $01 / 04 / 1999$ & DBR & $4 \%$ & $04 / 07 / 2009$ \\
\hline & $01 / 08 / 1999$ & DBR & $41 / 2 \%$ & $04 / 07 / 2009$ \\
\hline & $01 / 11 / 1999$ & DBR & $53 / 8 \%$ & $04 / 01 / 2010$ \\
\hline & $01 / 06 / 2000$ & DBR & $51 / 4 \%$ & $04 / 07 / 2010$ \\
\hline & $01 / 12 / 2000$ & DBR & $51 / 4 \%$ & $04 / 01 / 2011$ \\
\hline & $01 / 06 / 2001$ & DBR & $5 \%$ & $04 / 07 / 2011$ \\
\hline & $01 / 02 / 2002$ & DBR & $5 \%$ & $04 / 01 / 2012$ \\
\hline & $01 / 08 / 2002$ & DBR & $5 \%$ & $04 / 07 / 2012$ \\
\hline & $01 / 02 / 2003$ & DBR & $4.50 \%$ & $04 / 01 / 2013$ \\
\hline & $01 / 08 / 2003$ & DBR & $3.75 \%$ & $04 / 07 / 2013$ \\
\hline & $01 / 01 / 2004$ & DBR & $4.25 \%$ & $04 / 01 / 2014$ \\
\hline & $01 / 12 / 2004$ & DBR & $3.75 \%$ & $04 / 01 / 2015$ \\
\hline & $01 / 06 / 2005$ & DBR & $3.25 \%$ & $04 / 07 / 2015$ \\
\hline & $01 / 12 / 2005$ & DBR & $3.50 \%$ & $04 / 01 / 2016$ \\
\hline \multirow[t]{4}{*}{ IRELAND } & 01/10/1997 & IRISH & $6 \%$ & 18/08/2008 \\
\hline & 01/07/1999 & IRISH & $4 \%$ & $18 / 04 / 2010$ \\
\hline & $01 / 05 / 2002$ & IRISH & $5 \%$ & $18 / 04 / 2013$ \\
\hline & $01 / 05 / 2005$ & IRISH & $4.60 \%$ & $18 / 04 / 2016$ \\
\hline \multirow[t]{12}{*}{ ITALY } & $01 / 02 / 1998$ & BTPS & $6 \%$ & $01 / 11 / 2007$ \\
\hline & $01 / 07 / 1998$ & BTPS & $5 \%$ & $01 / 05 / 2008$ \\
\hline & 01/01/1999 & BTPS & $4.50 \%$ & 01/05/2009 \\
\hline & $01 / 10 / 1999$ & BTPS & $4.25 \%$ & $01 / 11 / 2009$ \\
\hline & $01 / 07 / 2000$ & BTPS & $5.50 \%$ & $01 / 11 / 2010$ \\
\hline & $01 / 06 / 2001$ & BTPS & $5.25 \%$ & $01 / 08 / 2011$ \\
\hline & $01 / 02 / 2002$ & BTPS & $5 \%$ & $01 / 02 / 2012$ \\
\hline & $01 / 10 / 2002$ & BTPS & $4.75 \%$ & 01/02/2013 \\
\hline & $01 / 07 / 2003$ & BTPS & $4.25 \%$ & $01 / 08 / 2013$ \\
\hline & $01 / 05 / 2004$ & BTPS & $4.25 \%$ & $01 / 08 / 2014$ \\
\hline & $01 / 02 / 2005$ & BTPS & $4.25 \%$ & $01 / 02 / 2015$ \\
\hline & $01 / 08 / 2005$ & BTPS & $3.75 \%$ & $01 / 08 / 2015$ \\
\hline \multirow[t]{8}{*}{ NETHERLAND } & $01 / 02 / 1998$ & NETHER & $5.25 \%$ & $15 / 07 / 2008$ \\
\hline & $01 / 02 / 1999$ & NETHER & $3.75 \%$ & $15 / 07 / 2009$ \\
\hline & $01 / 02 / 2000$ & NETHER & $5.50 \%$ & $15 / 07 / 2010$ \\
\hline & $01 / 04 / 2001$ & NETHER & $5 \%$ & $15 / 07 / 2011$ \\
\hline & $01 / 05 / 2002$ & NETHER & $5 \%$ & $15 / 07 / 2012$ \\
\hline & $01 / 04 / 2003$ & NETHER & $4.25 \%$ & $15 / 07 / 2013$ \\
\hline & $01 / 05 / 2004$ & NETHER & $3.75 \%$ & $15 / 07 / 2014$ \\
\hline & $01 / 07 / 2005$ & NETHER & $3.25 \%$ & $15 / 07 / 2015$ \\
\hline
\end{tabular}


Table 6 (cont)

\begin{tabular}{|c|c|c|c|c|}
\hline & Issue Date & Symbol & Coupon & Maturity Date \\
\hline \multirow[t]{8}{*}{ PORTUGAL } & 01/06/1998 & PGB & $5.375 \%$ & $23 / 06 / 2008$ \\
\hline & $01 / 07 / 1999$ & PGB & $3.95 \%$ & $15 / 07 / 2009$ \\
\hline & 01/06/2000 & PGB & $5.85 \%$ & $20 / 05 / 2010$ \\
\hline & 01/04/2001 & PGB & $5.15 \%$ & 15/06/2011 \\
\hline & $01 / 05 / 2002$ & PGB & $5 \%$ & $15 / 06 / 2012$ \\
\hline & $01 / 08 / 2003$ & PGB & $5.45 \%$ & $23 / 09 / 2013$ \\
\hline & $01 / 05 / 2004$ & PGB & $4.38 \%$ & $16 / 06 / 2014$ \\
\hline & $01 / 10 / 2005$ & PGB & $3.35 \%$ & $15 / 10 / 2015$ \\
\hline \multirow[t]{9}{*}{ SPAIN } & $01 / 11 / 1997$ & SPGB & $6 \%$ & $31 / 01 / 2008$ \\
\hline & $01 / 01 / 1999$ & SPGB & $5.15 \%$ & $30 / 07 / 2009$ \\
\hline & $01 / 01 / 2000$ & SPGB & $4.00 \%$ & $31 / 01 / 2010$ \\
\hline & $01 / 02 / 2001$ & SPGB & $5.40 \%$ & $30 / 07 / 2011$ \\
\hline & $01 / 10 / 2001$ & SPGB & $5.35 \%$ & $31 / 10 / 2011$ \\
\hline & $01 / 07 / 2002$ & SPGB & $5 \%$ & $30 / 07 / 2012$ \\
\hline & $01 / 08 / 2003$ & SPGB & $4.80 \%$ & $30 / 07 / 2013$ \\
\hline & $01 / 07 / 2004$ & SPGB & $4.75 \%$ & $30 / 07 / 2014$ \\
\hline & $01 / 01 / 2005$ & SPGB & $4.40 \%$ & $31 / 01 / 2015$ \\
\hline \multirow[t]{5}{*}{ DENMARK } & $01 / 07 / 1997$ & DGB & $7 \%$ & $15 / 11 / 2007$ \\
\hline & $01 / 02 / 1999$ & DGB & $6 \%$ & $15 / 11 / 2009$ \\
\hline & $01 / 03 / 2001$ & DGB & $6 \%$ & $15 / 11 / 2011$ \\
\hline & $01 / 03 / 2003$ & DGB & $5 \%$ & $15 / 11 / 2013$ \\
\hline & $01 / 03 / 2005$ & DGB & $4 \%$ & $15 / 11 / 2015$ \\
\hline \multirow[t]{5}{*}{ SWEDEN } & $01 / 07 / 1998$ & SGB & $9 \%$ & $20 / 04 / 2009$ \\
\hline & $01 / 02 / 2001$ & SGB & $5.25 \%$ & $15 / 03 / 2011$ \\
\hline & $01 / 08 / 2002$ & SGB & $5.50 \%$ & $08 / 10 / 2012$ \\
\hline & $01 / 02 / 2004$ & SGB & $6.75 \%$ & $05 / 05 / 2014$ \\
\hline & $01 / 05 / 2005$ & SGB & $4.50 \%$ & $12 / 08 / 2015$ \\
\hline \multirow[t]{7}{*}{ U.KINGDOM } & Oct-98 & UKT & $9 \%$ & $13 / 10 / 2008$ \\
\hline & Apr-99 & UKT & $5.75 \%$ & $07 / 12 / 2009$ \\
\hline & Apr-01 & UKT & $6.25 \%$ & $25 / 11 / 2010$ \\
\hline & Aug-01 & UKT & $5 \%$ & 07/03/2012 \\
\hline & Sep-03 & UKT & $8.50 \%$ & $27 / 09 / 2013$ \\
\hline & Dec-03 & UKT & $5 \%$ & 07/09/2014 \\
\hline & Mar-05 & UKT & $4.75 \%$ & $07 / 09 / 2015$ \\
\hline
\end{tabular}

Source: Datastream 
Table 7

\begin{tabular}{|c|c|c|c|c|}
\hline \multicolumn{5}{|c|}{$\begin{array}{l}\text { Cross-Sectional Time-Serie FGLS Regression. } \\
\text { dependent variable: SPREAD }\end{array}$} \\
\hline $\boldsymbol{X}_{i t}$ & $1999-2005$ & $1999-2000$ & 2001-1002 & $2003-2005$ \\
\hline LNDEBTGDP ${ }_{i t}$ & $\begin{array}{l}0.043^{\star \star} \\
(0.060)\end{array}$ & $\begin{array}{l}0.556^{\star \star} \\
(0.019)\end{array}$ & $\begin{array}{l}-0.159^{* *} \\
(0.028)\end{array}$ & $\begin{array}{l}-0.327^{\star *} \\
(0.012)\end{array}$ \\
\hline ONOFFDIF $_{i t}$ & $\begin{array}{l}0.480^{* *} \\
(0.024)\end{array}$ & $\begin{array}{l}0.407^{* *} \\
(0.107)\end{array}$ & $\begin{array}{c}-0.529^{\star *} \\
(0.054)\end{array}$ & $\begin{array}{l}-0.510^{\star *} \\
(0.046)\end{array}$ \\
\hline ONOFFDIF2 ${ }_{\text {it }}$ & $\begin{array}{c}-1.553^{\star \star} \\
(0.108)\end{array}$ & - & $\begin{array}{l}2.827^{\star *} \\
(0.385) \\
\end{array}$ & $\begin{array}{l}-2.881^{\star *} \\
(0.172)\end{array}$ \\
\hline BIDASKDIF $_{i t}$ & $\begin{array}{l}0.529^{\star *} \\
(0.033) \\
\end{array}$ & $\begin{array}{l}0.153^{\star *} \\
(0.053) \\
\end{array}$ & $\begin{array}{l}0.191^{\star \star} \\
(0.082) \\
\end{array}$ & $\begin{array}{l}0.471^{\star *} \\
(0.061) \\
\end{array}$ \\
\hline BIDASKDIF2 ${ }_{\text {it }}$ & $\begin{array}{l}0.874^{\star \star} \\
(0.362)\end{array}$ & $\begin{array}{l}-1.057^{*} \\
(0.567)\end{array}$ & $\begin{array}{l}1.382^{*} \\
(0.743)\end{array}$ & $\begin{array}{l}1.775^{\star *} \\
(0.757)\end{array}$ \\
\hline USSPREAD $_{i t}$ & $\begin{array}{l}0.008^{*} \\
(0.005) \\
\end{array}$ & - & - & $\begin{array}{c}-0.048^{* *} \\
(0.008)\end{array}$ \\
\hline${ }_{\text {LNDEBTGDP*USSPREAD }}$ it & $\begin{array}{l}0.007^{\star \star} \\
(0.002)\end{array}$ & $\begin{array}{l}0.018^{\star \star} \\
(0.008)\end{array}$ & $\begin{array}{l}0.010^{\star *} \\
(0.004)\end{array}$ & $\begin{array}{l}0.018^{\star *} \\
(0.003)\end{array}$ \\
\hline ONOFFDIF*USSPREAD $_{i t}$ & $\begin{array}{l}-0.500^{\star *} \\
(0.024)\end{array}$ & - & - & - \\
\hline ONOFFDIF2*USSPREAD $_{i t}$ & $\begin{array}{l}1.547^{\star *} \\
(0.094)\end{array}$ & $\begin{array}{l}-4.065^{\star *} \\
(-3.826)\end{array}$ & $\begin{array}{c}-0.792^{* *} \\
(0.238)\end{array}$ & $\begin{array}{l}2.381^{* *} \\
(0.148)\end{array}$ \\
\hline BIDASKDIF*USSPREAD $_{i t}$ & $\begin{array}{c}-0.303^{* *} \\
(0.037)\end{array}$ & - & - & $\begin{array}{c}-0.539^{* *} \\
(0.063)\end{array}$ \\
\hline BIDASKDIF2*USSPREAD $_{i t}$ & $\begin{array}{c}-0.997^{\star *} \\
(0.364)\end{array}$ & - & $\begin{array}{c}-1.687^{* *} \\
(0.604)\end{array}$ & - \\
\hline DAUSTRIA & $\begin{array}{l}0.056^{\star *} \\
(0.004)\end{array}$ & $\begin{array}{l}0.517^{* *} \\
(0.018)\end{array}$ & $\begin{array}{l}-0.182^{* *} \\
(0.026)\end{array}$ & $\begin{array}{l}0.320^{* *} \\
(0.008)\end{array}$ \\
\hline DBELGIUM & $\begin{array}{l}0.056^{\star \star} \\
(0.009)\end{array}$ & - & - & $\begin{array}{l}0.678^{* *} \\
(0.018)\end{array}$ \\
\hline DFINLAND & $\begin{array}{l}0.022^{* *} \\
(0.004)\end{array}$ & $\begin{array}{l}0.458^{* *} \\
(0.017)\end{array}$ & $\begin{array}{c}-0.215^{\star *} \\
(0.029)\end{array}$ & $\begin{array}{l}0.226^{* *} \\
(0.007)\end{array}$ \\
\hline DFRANCE & - & $\begin{array}{l}0.305^{* *} \\
(0.015)\end{array}$ & $\begin{array}{c}-0.234^{* *} \\
(0.214)\end{array}$ & $\begin{array}{l}0.510^{\star *} \\
(0.012)\end{array}$ \\
\hline DITALY & $\begin{array}{l}0.123^{\star *} \\
(0.008)\end{array}$ & $\begin{array}{l}0.056^{* *} \\
(0.002) \\
\end{array}$ & $\begin{array}{l}0.065^{* *} \\
(0.003) \\
\end{array}$ & $\begin{array}{l}0.761^{* *} \\
(0.017)\end{array}$ \\
\hline DNETHERLANDS & - & $\begin{array}{l}0.261^{* *} \\
(0.013)\end{array}$ & $\begin{array}{l}0.240^{* *} \\
(0.024)\end{array}$ & $\begin{array}{l}0.423^{* *} \\
(0.010)\end{array}$ \\
\hline DPORTUGAL & $\begin{array}{l}0.107^{* *} \\
(0.004)\end{array}$ & $\begin{array}{l}0.630^{* *} \\
(0.020)\end{array}$ & $\begin{array}{c}-0.114^{\star *} \\
(0.028)\end{array}$ & $\begin{array}{l}0.466^{* *} \\
(0.011)\end{array}$ \\
\hline DSPAIN & $\begin{array}{l}0.059^{\star *} \\
(0.005)\end{array}$ & $\begin{array}{l}0.352^{* *} \\
(0.012)\end{array}$ & $\begin{array}{c}-0.102^{* *} \\
(0.020)\end{array}$ & $\begin{array}{l}0.388^{* *} \\
(0.010)\end{array}$ \\
\hline CONSTANT & $\begin{array}{l}0.072^{\star *} \\
(0.006)\end{array}$ & $\begin{array}{c}-0.478^{\star *} \\
(0.024)\end{array}$ & $\begin{array}{c}0.4451^{\star *} \\
(0.033)\end{array}$ & $\begin{array}{l}-0.267^{\star *} \\
(0.017)\end{array}$ \\
\hline $\begin{array}{l}\text { Number of observations = } \\
\text { Number of groups = } \\
\text { Avg obs per group = } \\
\text { Log likelihood = } \\
\text { Wald chi2 = } \\
\text { Prob }>\text { chi2 = }\end{array}$ & $\begin{array}{c}14674 \\
9 \\
1669 \\
30311.21 \\
102334.55 \\
0.00\end{array}$ & $\begin{array}{c}4253 \\
9 \\
500 \\
9864.034 \\
1741.75 \\
0.00\end{array}$ & $\begin{array}{c}4174 \\
9 \\
494 \\
9683.918 \\
31258.25 \\
0.00\end{array}$ & $\begin{array}{c}6254 \\
9 \\
696 \\
14767.5 \\
25701.7 \\
0.00 \\
\end{array}$ \\
\hline
\end{tabular}

**Significant at 5 percent confidence level.

*Significant at 10 percent confidence level.

Standard Errors within parentheses 
Table 8 a

\begin{tabular}{|c|c|c|c|c|c|c|c|c|c|c|c|c|}
\hline \multicolumn{13}{|c|}{$\begin{array}{l}\text { Regression with Newey-West Standard Errors } \\
\text { dependent variable: SPREAD }\end{array}$} \\
\hline & \multicolumn{4}{|c|}{ AUSTRIA } & \multicolumn{4}{|c|}{ BELGIUM } & \multicolumn{4}{|c|}{ FINLAND } \\
\hline$X_{t}$ & 1999-2005 & $1999-2000$ & $2001-1002$ & 2003-2005 & 1999-2005 & 1999-2000 & $2001-1002$ & 2003-2005 & 1999-2005 & 1999-2000 & $2001-1002$ & 2003-2005 \\
\hline LNDEBTGDP $_{t}$ & & & - & $\begin{array}{l}0.292^{* *} \\
(0.098)\end{array}$ & $\begin{array}{l}0.261^{*} \\
(0.140)\end{array}$ & - & $\begin{array}{l}1.198^{* *} \\
(0.451)\end{array}$ & $\begin{array}{l}0.413^{* *} \\
(0.100)\end{array}$ & $\begin{array}{l}0.195^{* *} \\
(0.090)\end{array}$ & - & - & $\begin{array}{l}0.414^{* *} \\
(0.078)\end{array}$ \\
\hline ONOFFDIF $_{t}$ & $\begin{array}{l}-0.728^{* *} \\
(0.065)\end{array}$ & $\begin{array}{l}0.625^{* *} \\
(0.316)\end{array}$ & $\begin{array}{c}-0.662^{* *} \\
(0.179)\end{array}$ & $\begin{array}{c}-0.942^{* *} \\
(0.030)\end{array}$ & $\begin{array}{c}-0.435^{* *} \\
(0.083)\end{array}$ & - & $\begin{array}{c}-1.236^{* *} \\
(0.223)\end{array}$ & $\begin{array}{c}-0.995^{* \star} \\
(0.057)\end{array}$ & $\begin{array}{c}-0.576^{* *} \\
(0.128\end{array}$ & 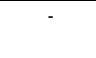 & $\begin{array}{c}-0.748^{* *} \\
(0.134)\end{array}$ & $\begin{array}{c}-1.029^{* *} \\
(0.090)\end{array}$ \\
\hline ONOFFDIF2 ${ }_{t}$ & $\begin{array}{l}1.647^{* *} \\
(0.292)\end{array}$ & - & - & - & $\begin{array}{l}6.306^{* *} \\
(0.846)\end{array}$ & - & - & - & $\begin{array}{l}1.458^{* *} \\
(0.472)\end{array}$ & $\begin{array}{l}4.052^{*} \\
(2.094)\end{array}$ & - & - \\
\hline BIDASKDIF $_{t}$ & $\begin{array}{c}0.272^{*} \\
(0.153)\end{array}$ & $\begin{array}{l}-0.376^{*} \\
(0.223)\end{array}$ & - & $\begin{array}{l}0.514^{* *} \\
(0.158)\end{array}$ & - & - & - & $\begin{array}{l}0.597^{* *} \\
(0.119)\end{array}$ & - & - & - & - \\
\hline BIDASKDIF2 $_{t}$ & $\begin{array}{c}-0.764^{\star *} \\
(0.418)\end{array}$ & - & - & $\begin{array}{c}-1.427^{\star *} \\
(0.501)\end{array}$ & - & - & $\begin{array}{c}13.918^{* *} \\
(5.358)\end{array}$ & $\begin{array}{l}3.549^{* *} \\
(1.149)\end{array}$ & - & - & - & $\begin{array}{l}6.674^{* *} \\
(3.160)\end{array}$ \\
\hline USSPREAD $_{t}$ & - & $\begin{array}{l}0.200^{*} \\
(0.116) \\
\end{array}$ & $\begin{array}{c}-0.096^{* *} \\
(0.041)\end{array}$ & $\begin{array}{l}-0.034^{\star *} \\
(0.010)\end{array}$ & $\begin{array}{c}-0.130^{* *} \\
(0.044) \\
\end{array}$ & - & $\begin{array}{l}0.391^{*} \\
(0.223) \\
\end{array}$ & - & - & - & $\begin{array}{c}-0.025^{* *} \\
(0.009) \\
\end{array}$ & $\begin{array}{c}-0.089^{* *} \\
(0.018) \\
\end{array}$ \\
\hline${ }_{\text {LNDEBTGDP*USSPREAD }} t$ & $\begin{array}{l}0.288^{* *} \\
(0.052)\end{array}$ & $\begin{array}{l}-0.962^{*} \\
(0.577)\end{array}$ & $\begin{array}{l}1.009^{* *} \\
(0.293)\end{array}$ & $\begin{array}{c}-0.256^{* *} \\
(0.083)\end{array}$ & $\begin{array}{l}0.143^{\star *} \\
(0.045)\end{array}$ & - & $\begin{array}{l}0.344^{*} \\
(0.209)\end{array}$ & - & - & - & - & $\begin{array}{c}-0.229^{* *} \\
(0.076)\end{array}$ \\
\hline ONOFFDIF*USSPREAD $_{t}$ & - & - & - & - & $\begin{array}{c}-0.414^{\star \star} \\
(0.086)\end{array}$ & - & $\begin{array}{c}0.304^{*} \\
(0.167)\end{array}$ & - & - & - & $\begin{array}{c}-0.266^{* *} \\
(0.105)\end{array}$ & - \\
\hline ONOFFDIF2*USSPREAD $_{t}$ & $\begin{array}{c}-1.018^{* *} \\
(0.234) \\
\end{array}$ & - & - & $\begin{array}{c}-0.233^{\star \star} \\
(0.117) \\
\end{array}$ & $\begin{array}{l}-4.490^{* *} \\
(0.751) \\
\end{array}$ & - & - & - & $\begin{array}{c}-0.753^{\star *} \\
(0.335)\end{array}$ & - & - & - \\
\hline BIDASKDIF*USSPREAD $_{t}$ & $\begin{array}{c}-0.330^{* *} \\
(0.165) \\
\end{array}$ & $\begin{array}{l}0.833^{* *} \\
(0.419) \\
\end{array}$ & - & $\begin{array}{c}-0.455^{\star *} \\
(0.143)\end{array}$ & $\begin{array}{c}-0.275^{* *} \\
(0.120)\end{array}$ & - & $\begin{array}{c}-0.652^{*} \\
(1.611) \\
\end{array}$ & $\begin{array}{c}-0.621^{\star *} \\
(0.126) \\
\end{array}$ & - & - & - & - \\
\hline BIDASKDIF2*USSPREAD $_{t}$ & $\begin{array}{l}0.969^{* *} \\
(0.441)\end{array}$ & - & - & $\begin{array}{l}1.272^{* *} \\
(0.469)\end{array}$ & $\begin{array}{c}2.806^{*} \\
(1.469)\end{array}$ & - & $\begin{array}{l}-9.122^{*} \\
(4.814)\end{array}$ & - & - & - & - & $\begin{array}{c}-7.841^{* *} \\
(3.412)\end{array}$ \\
\hline CONSTANT & $\begin{array}{l}0.112^{\star \star} \\
(0.018)\end{array}$ & - & - & - & - & - & $\begin{array}{l}-0.924^{*} \\
(0.499)\end{array}$ & $\begin{array}{l}-0.387^{* *} \\
(0.089)\end{array}$ & $\begin{array}{l}0.163^{* *} \\
(0.022)\end{array}$ & $\begin{array}{l}0.188^{*} \\
(0.099)\end{array}$ & - & $\begin{array}{l}0.087^{* *} \\
(0.035)\end{array}$ \\
\hline $\begin{array}{l}\text { Number of obs } \\
F=\end{array}$ & $\begin{array}{c}1748 \\
2080.63\end{array}$ & $\begin{array}{c}513 \\
229.8\end{array}$ & $\begin{array}{c}521 \\
453.2\end{array}$ & $\begin{array}{c}714 \\
3726.1\end{array}$ & $\begin{array}{c}1755 \\
2482.82\end{array}$ & $\begin{array}{c}516 \\
158.57\end{array}$ & $\begin{array}{c}522 \\
785.09\end{array}$ & $\begin{array}{c}717 \\
3898.08\end{array}$ & $\begin{array}{c}1742 \\
2410.33\end{array}$ & $\begin{array}{c}505 \\
24.72\end{array}$ & $\begin{array}{c}520 \\
662.46\end{array}$ & $\begin{array}{c}717 \\
1194.5\end{array}$ \\
\hline Prob > F = & 0.00 & 0.00 & 0.00 & 0.00 & 0.00 & 0.00 & 0.00 & 0.00 & 0.00 & 0.00 & 0.00 & 0.00 \\
\hline
\end{tabular}

**Significant at 5 percent confidence level.

*Significant at 10 percent confidence level.

Standard Errors within parentheses

Table 8b

\begin{tabular}{|c|c|c|c|c|c|c|c|c|c|c|c|c|}
\hline \multicolumn{13}{|c|}{$\begin{array}{l}\text { Regression with Newey-West Standard Errors } \\
\text { dependent variable: SPREAD }\end{array}$} \\
\hline & \multicolumn{4}{|c|}{ FRANCE } & \multicolumn{4}{|c|}{ IRELAND } & \multicolumn{4}{|c|}{ ITALY } \\
\hline$X_{t}$ & 1999-2005 & 1999-2000 & 2001-1002 & 2003-2005 & $1999-2005$ & $1999-2000$ & 2001-1002 & 2003-2005 & $1999-2005$ & 1999-2000 & 2001-1002 & 2003-2005 \\
\hline LNDEBTGDP $t$ & $\begin{array}{c}-1.647^{\star *} \\
(0.566) \\
\end{array}$ & $\begin{array}{c}-4.854^{\star \star} \\
(1.609) \\
\end{array}$ & - & $\begin{array}{l}0.865^{\star \star} \\
(0.157) \\
\end{array}$ & - & - & - & - & $\begin{array}{c}-0.322^{\star \star} \\
(0.123) \\
\end{array}$ & $\begin{array}{c}-1.000^{\star *} \\
(0.336) \\
\end{array}$ & $\begin{array}{l}2.552^{\star \star} \\
(0.323) \\
\end{array}$ & $\begin{array}{l}0.863^{\star \star} \\
(0.147) \\
\end{array}$ \\
\hline ONOFFDIF $_{t}$ & $\begin{array}{c}-0.832^{\star \star} \\
(0.040) \\
\end{array}$ & - & $\begin{array}{c}-0.948^{\star \star} \\
(0.064) \\
\end{array}$ & $\begin{array}{c}-0.993^{\star *} \\
(0.012) \\
\end{array}$ & $\begin{array}{l}0.203^{\star \star} \\
(0.097) \\
\end{array}$ & - & - & - & $\begin{array}{c}-0.214^{\star \star} \\
(0.102) \\
\end{array}$ & $\begin{array}{l}1.360^{\star \star} \\
(0.342) \\
\end{array}$ & $\begin{array}{c}-1.220^{\star \star} \\
(0.220) \\
\end{array}$ & $\begin{array}{c}-0.890^{\star \star} \\
(0.067) \\
\end{array}$ \\
\hline ONOFFDIF2 $_{t}$ & $\begin{array}{l}1.149^{\star \star} \\
(0.541)\end{array}$ & - & - & - & $\begin{array}{l}1.414^{\star \star} \\
(0.357) \\
\end{array}$ & - & $\begin{array}{l}3.644^{\star \star} \\
(1.132)\end{array}$ & $\begin{array}{l}0.684^{\star} \\
(0.403) \\
\end{array}$ & $\begin{array}{l}3.166^{\star \star} \\
(0.820) \\
\end{array}$ & - & $\begin{array}{l}3.450^{\star} \\
(1.757) \\
\end{array}$ & - \\
\hline BIDASKDIF $_{t}$ & - & - & $\begin{array}{c}-2.469^{\star \star} \\
(0.936) \\
\end{array}$ & $\begin{array}{c}-0.217^{\star \star} \\
(0.070) \\
\end{array}$ & $\begin{array}{l}0.719^{\star \star} \\
(0.273) \\
\end{array}$ & - & $\begin{array}{l}10.934^{*} \\
(6.597)\end{array}$ & - & $\begin{array}{c}0.129^{\star} \\
(0.071) \\
\end{array}$ & - & - & $\begin{array}{c}-0.308^{\star *} \\
(0.184) \\
\end{array}$ \\
\hline BIDASKDIF2 ${ }_{t}$ & - & $\begin{array}{c}-13.533^{\star *} \\
(6.332) \\
\end{array}$ & - & $\begin{array}{c}-1.519^{\star \star} \\
(0.623) \\
\end{array}$ & $\begin{array}{l}-9.077^{\star} \\
(5.252) \\
\end{array}$ & - & $\begin{array}{r}-145.522^{\star} \\
(74.633) \\
\end{array}$ & - & $\begin{array}{c}-4.065^{\star \star} \\
(1.188) \\
\end{array}$ & $\begin{array}{c}-9.224^{\star \star} \\
(1.992) \\
\end{array}$ & - & - \\
\hline USSPREAD $t$ & - & - & - & $\begin{array}{l}0.312^{* *} \\
(0.046) \\
\end{array}$ & - & $\begin{array}{l}-0.380^{*} \\
(0.198) \\
\end{array}$ & - & - & $\begin{array}{l}0.100^{\star *} \\
(0.051) \\
\end{array}$ & - & $\begin{array}{l}0.600^{* *} \\
(0.181) \\
\end{array}$ & $\begin{array}{l}0.524^{* \star} \\
(0.101) \\
\end{array}$ \\
\hline${ }_{\text {LNDEBTGDP*USSPREAD }} t$ & - & - & - & $\begin{array}{l}0.992^{\star *} \\
(0.151) \\
\end{array}$ & $\begin{array}{l}0.332^{\star \star} \\
(0.146) \\
\end{array}$ & $\begin{array}{c}-1.139^{\star *} \\
(0.515) \\
\end{array}$ & - & - & - & - & $\begin{array}{c}-0.553^{\star \star} \\
(0.180) \\
\end{array}$ & $\begin{array}{c}-0.644^{\star \star} \\
(0.124) \\
\end{array}$ \\
\hline ONOFFDIF*USSPREAD $_{t}$ & $\begin{array}{c}-0.123^{* *} \\
(0.033) \\
\end{array}$ & - & - & - & $\begin{array}{c}-0.393^{\star *} \\
(0.114) \\
\end{array}$ & $\begin{array}{r}1.653^{*} \\
(0.940) \\
\end{array}$ & - & - & $\begin{array}{l}0.643^{\star \star} \\
(0.094) \\
\end{array}$ & - & $\begin{array}{l}0.282^{*} \\
(0.148) \\
\end{array}$ & $\begin{array}{l}-0.110^{*} \\
(0.065) \\
\end{array}$ \\
\hline ONOFFDIF2 $^{*} U S S P R E A D_{t}$ & $\begin{array}{c}-0.874^{\star \star} \\
(0.435)\end{array}$ & - & - & - & $\begin{array}{c}-0.857^{\star \star} \\
(0.302) \\
\end{array}$ & - & $\begin{array}{c}-2.347^{\star \star} \\
(0.838) \\
\end{array}$ & - & $\begin{array}{c}-2.691^{\star \star} \\
(0.656)\end{array}$ & - & - & - \\
\hline BIDASKDIF*USSPREAD $_{t}$ & - & - & $\begin{array}{l}2.318^{\star \star} \\
(0.773) \\
\end{array}$ & $\begin{array}{l}0.221^{\star *} \\
(0.076) \\
\end{array}$ & $\begin{array}{c}-1.037^{\star \star} \\
(0.443) \\
\end{array}$ & - & - & $\begin{array}{c}-1.085^{\star \star} \\
(0.487) \\
\end{array}$ & $\begin{array}{c}-0.288^{\star \star} \\
(0.073) \\
\end{array}$ & - & - & - \\
\hline BIDASKDIF2 $^{*} U S S P R E A D_{t}$ & - & - & - & - & $\begin{array}{l}13.466^{*} \\
(7.595)\end{array}$ & - & - & - & $\begin{array}{l}5.034^{\star \star} \\
(1.412)\end{array}$ & $\begin{array}{c}11.008^{\star *} \\
(3.228) \\
\end{array}$ & - & - \\
\hline CONSTANT & $\begin{array}{l}0.741^{\star \star} \\
(0.212) \\
\end{array}$ & $\begin{array}{l}1.990^{\star *} \\
(0.627) \\
\end{array}$ & - & $\begin{array}{c}-0.222^{\star *} \\
(0.048) \\
\end{array}$ & - & $\begin{array}{l}0.335^{\star \star} \\
(0.131) \\
\end{array}$ & - & $\begin{array}{c}-0.852^{\star \star} \\
(0.390) \\
\end{array}$ & - & $\begin{array}{l}1.495^{\star \star} \\
(0.398) \\
\end{array}$ & $\begin{array}{c}-2.296^{\star \star} \\
(0.330) \\
\end{array}$ & $\begin{array}{c}-0.530^{\star *} \\
(0.121) \\
\end{array}$ \\
\hline Number of obs & 1739 & 508 & 517 & 714 & 936 & 149 & 147 & 640 & 1756 & 517 & 522 & 717 \\
\hline $\mathbf{F}=$ & 1013.24 & 21.79 & 339.24 & 3495.14 & 1358.62 & 135.88 & 211.60 & 580.03 & 1942.83 & 293.27 & 1227.55 & 1582.69 \\
\hline Prob $>F=$ & 0.00 & 0.00 & 0.00 & 0.00 & 0.00 & 0.00 & 0.00 & 0.00 & 0.00 & 0.00 & 0.00 & 0.00 \\
\hline
\end{tabular}

${ }^{*}$ Significant at 5 percent confidence level.

* Significant at 10 percent confidence level.

Standard Errors within parentheses 
Table 8c

Regression with Newey-West Standard Errors dependent variable: SPREAD

\begin{tabular}{|c|c|c|c|c|c|c|c|c|c|c|c|c|}
\hline & \multicolumn{4}{|c|}{ THE NETHERLANDS } & \multicolumn{4}{|c|}{ PORTUGAL } & \multicolumn{4}{|c|}{ SPAIN } \\
\hline $\boldsymbol{X}_{t}$ & 1999-2005 & 1999-2000 & 2001-1002 & 2003-2005 & 1999-2005 & 1999-2000 & 2001-1002 & $2003-2005$ & 1999-2005 & 1999-2000 & $2001-1002$ & 2003-2005 \\
\hline LNDEBTGDP $_{t}$ & $\begin{array}{l}0.322^{\star} \\
(0.179)\end{array}$ & - & - & - & $\begin{array}{l}0.957^{\star \star} \\
(0.404)\end{array}$ & - & - & $\begin{array}{c}-0.450^{\star *} \\
(0.183)\end{array}$ & - & - & - & $\begin{array}{l}0.193^{\star \star} \\
(0.093)\end{array}$ \\
\hline ONOFFDIF $_{t}$ & $\begin{array}{c}-0.485^{\star \star} \\
(0.080)\end{array}$ & - & $\begin{array}{l}-0.844^{\star \star} \\
(0.195)\end{array}$ & $\begin{array}{l}-0.520^{\star *} \\
(0.096)\end{array}$ & $\begin{array}{c}-0.815^{\star \star} \\
(0.086)\end{array}$ & $\begin{array}{l}-1.224^{\star} \\
(0.632)\end{array}$ & - & $\begin{array}{c}-1.025^{\star \star} \\
(0.069)\end{array}$ & $\begin{array}{c}-0.327^{* *} \\
(0.119)\end{array}$ & - & - & $\begin{array}{l}-0.815^{\star \star} \\
(0.064)\end{array}$ \\
\hline ONOFFDIF2 $_{t}$ & $\begin{array}{l}3.672^{\star *} \\
(0.753)\end{array}$ & - & - & $\begin{array}{l}1.576^{\star *} \\
(0.658)\end{array}$ & $\begin{array}{l}1.525^{\star \star} \\
(0.429)\end{array}$ & - & $\begin{array}{l}-0.773^{*} \\
(0.403)\end{array}$ & - & $\begin{array}{l}6.191^{\star \star} \\
(1.468)\end{array}$ & - & - & $\begin{array}{c}-1.239^{\star *} \\
(0.594)\end{array}$ \\
\hline BIDASKDIF $_{t}$ & - & - & - & - & $\begin{array}{l}0.298^{\star *} \\
(0.118)\end{array}$ & - & - & - & - & - & - & $\begin{array}{l}0.440^{\star \star} \\
(0.095)\end{array}$ \\
\hline BIDASKDIF2 $_{t}$ & - & - & - & - & - & - & - & - & - & - & - & $\begin{array}{l}-2.832 \\
(1.120)\end{array}$ \\
\hline USSPREAD $_{t}$ & - & - & - & $\begin{array}{l}-0.070^{*} \\
(0.042)\end{array}$ & $\begin{array}{l}0.221^{* *} \\
(0.045)\end{array}$ & $\begin{array}{c}-0.289^{\star \star} \\
(0.109)\end{array}$ & $\begin{array}{l}0.317^{\star \star} \\
(0.086)\end{array}$ & $\begin{array}{c}-0.164^{\star \star} \\
(0.039)\end{array}$ & - & - & - & - \\
\hline LNDEBTGDP $^{\star} U S S P R E A D_{t}$ & - & - & - & - & $\begin{array}{l}-0.863^{\star *} \\
(0.206)\end{array}$ & $\begin{array}{l}2.472^{\star} \\
(1.267)\end{array}$ & $\begin{array}{c}-1.734^{\star \star} \\
(0.696)\end{array}$ & $\begin{array}{l}0.725^{\star \star} \\
(0.168)\end{array}$ & $\begin{array}{l}0.109^{\star \star} \\
(0.048)\end{array}$ & - & - & - \\
\hline ONOFFDIF*USSPREAD $_{t}$ & $\begin{array}{l}0.323^{\star \star} \\
(0.072)\end{array}$ & - & - & $\begin{array}{l}-0.384^{\star *} \\
(0.100)\end{array}$ & - & $\begin{array}{l}1.774^{\star \star} \\
(0.855)\end{array}$ & - & $\begin{array}{l}0.100^{\star \star} \\
(0.049)\end{array}$ & $\begin{array}{c}-0.438^{\star *} \\
(0.125)\end{array}$ & - & $\begin{array}{l}-0.688^{\star \star} \\
(0.322)\end{array}$ & \\
\hline ONOFFDIF2 $^{*}$ USSPREAD $_{t}$ & $\begin{array}{l}-2.420^{\star *} \\
(0.595)\end{array}$ & $\begin{array}{c}-11.240^{\star \star} \\
(5.180)\end{array}$ & - & $\begin{array}{c}-1.444^{\star \star} \\
(0.614)\end{array}$ & $\begin{array}{l}-0.866^{\star *} \\
(0.282)\end{array}$ & - & - & - & $\begin{array}{l}-4.003^{* \star} \\
(1.261)\end{array}$ & - & - & $\begin{array}{l}1.400^{\star \star} \\
(0.645)\end{array}$ \\
\hline BIDASKDIF $^{*}$ USSPREAD $_{t}$ & - & - & - & - & $\begin{array}{l}-0.412^{\star \star} \\
(0.145)\end{array}$ & - & - & - & - & - & - & $\begin{array}{c}-0.514^{\star \star} \\
(0.106)\end{array}$ \\
\hline BIDASKDIF2*USSPREAD $_{t}$ & - & - & - & - & - & - & - & - & - & - & - & $\begin{array}{l}3.549^{\star \star} \\
(1.127)\end{array}$ \\
\hline CONSTANT & - & - & - & - & - & $\begin{array}{l}0.265^{\star \star} \\
(0.090)\end{array}$ & - & $\begin{array}{l}0.175^{\star \star} \\
(0.044)\end{array}$ & - & - & - & $\begin{array}{l}-0.014^{\star \star} \\
(0.005)\end{array}$ \\
\hline Number of obs & 1691 & 517 & 513 & 661 & 1402 & 511 & 522 & 717 & 1557 & 517 & 390 & 650 \\
\hline$F=$ & 616.11 & 8.45 & 302.59 & 413.25 & 3786.13 & 75.48 & 1455.87 & 4306.99 & 3635.23 & 65.53 & 925.85 & 374.91 \\
\hline Prob $>F=$ & 0.00 & 0.00 & 0.00 & 0.00 & 0.00 & 0.00 & 0.00 & 0.00 & 0.00 & 0.00 & 0.00 & 0.00 \\
\hline
\end{tabular}

**Significant at 5 percent confidence level.

*Significant at 10 percent confidence level.

Standard Errors within parentheses 
Table 9

\begin{tabular}{|c|c|c|c|c|}
\hline \multicolumn{5}{|c|}{$\begin{array}{l}\text { Cross-Sectional Time-Serie FGLS Regression. } \\
\text { dependent variable: ASPREAD }\end{array}$} \\
\hline $\boldsymbol{X}_{i t}$ & $1999-2005$ & $1999-2000$ & 2001-1002 & 2003-2005 \\
\hline LNDEBTGDP ${ }_{i t}$ & $\begin{array}{c}-0.554^{* *} \\
(0.024)\end{array}$ & $\begin{array}{l}0.637^{\star *} \\
(0.248)\end{array}$ & $\begin{array}{c}-0.597^{* *} \\
(0.049)\end{array}$ & $\begin{array}{c}-0.108^{\star *} \\
(0.035)\end{array}$ \\
\hline ONOFFDIF $_{i t}$ & $\begin{array}{l}0.776^{\star \star} \\
(0.044) \\
\end{array}$ & $\begin{array}{l}3.631^{\star \star} \\
(0.337) \\
\end{array}$ & - & - \\
\hline ONOFFDIF2 ${ }_{i t}$ & $\begin{array}{l}3.662^{\star *} \\
(0.282)\end{array}$ & $\begin{array}{c}-17.711^{* *} \\
(2.734)\end{array}$ & - & $\begin{array}{l}1.100^{\star *} \\
(0.484)\end{array}$ \\
\hline BIDASKDIF $_{i t}$ & $\begin{array}{l}0.300^{\star \star} \\
(0.140)\end{array}$ & $\begin{array}{c}-2.392^{\star *} \\
(0.414)\end{array}$ & $\begin{array}{c}-0.889^{\star *} \\
(0.348)\end{array}$ & $\begin{array}{l}1.198^{\star \star} \\
(0.161)\end{array}$ \\
\hline BIDASKDIF2 ${ }_{i t}$ & - & $\begin{array}{c}34.105^{\star \star} \\
(6.208)\end{array}$ & $\begin{array}{l}-6.962^{\star *} \\
(2.791)\end{array}$ & $\begin{array}{l}-4.503^{\star *} \\
(1.444)\end{array}$ \\
\hline USSPREAD $i t$ & $\begin{array}{l}0.717^{\star *} \\
(0.010)\end{array}$ & $\begin{array}{l}0.758^{\star *} \\
(0.112)\end{array}$ & $\begin{array}{c}-0.039^{* \star} \\
(0.014)\end{array}$ & $\begin{array}{l}0.034^{* *} \\
(0.011)\end{array}$ \\
\hline LNDEBTGDP*USSPREAD ${ }_{i t}$ & $\begin{array}{l}0.251^{\star \star} \\
(0.016)\end{array}$ & $\begin{array}{l}-2.192^{\star *} \\
(0.405)\end{array}$ & $\begin{array}{l}0.238^{\star \star} \\
(0.020)\end{array}$ & $\begin{array}{l}0.127^{\star \star} \\
(0.033)\end{array}$ \\
\hline ONOFFDIF*USSPREAD ${ }_{i t}$ & $\begin{array}{c}-0.541^{* *} \\
(0.043)\end{array}$ & $\begin{array}{c}-4.782^{\star *} \\
(0.667)\end{array}$ & $\begin{array}{l}0.237^{\star *} \\
(0.065) \\
\end{array}$ & $\begin{array}{l}0.453^{\star \star} \\
(0.144) \\
\end{array}$ \\
\hline ONOFFDIF2*USSPREAD ${ }_{i t}$ & $\begin{array}{l}-3.819^{\star \star} \\
(0273)\end{array}$ & $\begin{array}{c}19.747^{\star \star} \\
(5.473)\end{array}$ & - & - \\
\hline$B_{I D A S K D I F}{ }^{\star} U S S P R E A D_{i t}$ & $\begin{array}{c}-0.691^{\star *} \\
(0.174)\end{array}$ & $\begin{array}{l}4.864^{\star *} \\
(0.777)\end{array}$ & - & $\begin{array}{c}-1.789^{\star *} \\
(0.203)\end{array}$ \\
\hline BIDASKDIF2*USSPREAD $_{i t}$ & - & $\begin{array}{c}-64.322^{\star *} \\
(10.581)\end{array}$ & $\begin{array}{l}6.525^{\star \star} \\
(2.971)\end{array}$ & $\begin{array}{l}11.563^{\star *} \\
(1.828)\end{array}$ \\
\hline DSWEDEN & $\begin{array}{l}-0.201^{* *} \\
(0.003)\end{array}$ & $\begin{array}{c}-0.283^{\star *} \\
(0.007)\end{array}$ & $\begin{array}{c}-0.153^{* *} \\
(0.006)\end{array}$ & $\begin{array}{c}-0.182^{* *} \\
(0.007)\end{array}$ \\
\hline DUNITED KINGDOM & $\begin{array}{c}-0.368^{\star *} \\
(0.007)\end{array}$ & - & $\begin{array}{c}-0.380^{\star \star} \\
(0.018)\end{array}$ & $\begin{array}{c}-0.181^{\star *} \\
(0.014)\end{array}$ \\
\hline CONSTANT & $\begin{array}{l}0.094^{* *} \\
(0.011)\end{array}$ & $\begin{array}{c}-0.222^{* *} \\
(0.080) \\
\end{array}$ & $\begin{array}{l}0.177^{\star *} \\
(0.020)\end{array}$ & - \\
\hline $\begin{array}{l}\text { Number of observations = } \\
\text { Number of groups = } \\
\text { Avg obs per group = } \\
\text { Log likelihood = } \\
\text { Wald chi2 = } \\
\text { Prob }>\text { chi2 = }\end{array}$ & $\begin{array}{c}4715 \\
3 \\
1611 \\
9518.28 \\
20059.37 \\
0.00\end{array}$ & $\begin{array}{c}1030 \\
3 \\
515 \\
1901.09 \\
5962.64 \\
0.00\end{array}$ & $\begin{array}{c}1392 \\
3 \\
466 \\
3303.71 \\
9637.16 \\
0.00\end{array}$ & $\begin{array}{c}2293 \\
3 \\
765 \\
5124.37 \\
9348.36 \\
0.00\end{array}$ \\
\hline
\end{tabular}

**Significant at 5 percent confidence level.

*Significant at 10 percent confidence level.

Standard Errors within parentheses 
Table 10

\begin{tabular}{|c|c|c|c|c|c|c|c|c|c|c|c|c|}
\hline \multicolumn{13}{|c|}{$\begin{array}{l}\text { Regression with Newey-West Standard Errors } \\
\text { dependent variable: ASPREAD }\end{array}$} \\
\hline & \multicolumn{4}{|c|}{ DENMARK } & \multicolumn{5}{|c|}{ SWEDEN } & \multicolumn{3}{|c|}{ UNITED KINGDOM } \\
\hline$\overline{X_{t}}$ & 1999-2005 & 1999-2000 & 2001-1002 & 2003-2005 & 1999-2005 & $1999-2000$ & 2001-1002 & 2003-2005 & 1999-2005 & $1999-2000$ & 2001-1002 & 2003-2005 \\
\hline LNDEBTGDP ${ }_{t}$ & - & $\begin{array}{l}-1.193^{* *} \\
(0.566)\end{array}$ & $\begin{array}{l}1.362^{\star \star} \\
(0.436)\end{array}$ & - & $\begin{array}{l}-0.872^{\star *} \\
(0.157)\end{array}$ & $\begin{array}{c}-1.168^{\star *} \\
(0.353)\end{array}$ & $\begin{array}{l}1.090^{\star \star} \\
(0.570)\end{array}$ & $\begin{array}{l}-0.751^{\star *} \\
(0.201)\end{array}$ & - & - & - & - \\
\hline ONOFFDIF $_{t}$ & - & $\begin{array}{l}-1.179^{*} \\
(0.697)\end{array}$ & $\begin{array}{l}0.763^{\star *} \\
(0.303)\end{array}$ & - & $\begin{array}{l}0.731^{\star \star} \\
(0.316)\end{array}$ & $\begin{array}{l}1.657^{\star \star} \\
(0.487)\end{array}$ & $\begin{array}{c}-1.182^{\star \star} \\
(0.380)\end{array}$ & - & - & - & - & $\begin{array}{c}-0.790^{\star *} \\
(0.402) \\
\end{array}$ \\
\hline ONOFFDIF2 $_{t}$ & $\begin{array}{l}1.450^{\star *} \\
(0.643)\end{array}$ & $\begin{array}{l}9.343^{\star \star} \\
(4.476)\end{array}$ & - & - & $\begin{array}{l}5.428^{\star} \\
(3.281)\end{array}$ & - & $\begin{array}{c}-18.133^{* *} \\
(5.289)\end{array}$ & - & - & - & - & - \\
\hline BIDASKDIF $_{t}$ & $\begin{array}{l}0.828^{\star *} \\
(0.344)\end{array}$ & $\begin{array}{l}3.432^{\star} \\
(0.020)\end{array}$ & - & $\begin{array}{l}0.927^{\star \star} \\
(0.328)\end{array}$ & - & - & - & - & - & - & $\begin{array}{l}-4.953^{\star *} \\
(2.132)\end{array}$ & - \\
\hline BIDASKDIF2 $t$ & $\begin{array}{c}-15.815^{* *} \\
6.182)\end{array}$ & $\begin{array}{l}-76.229^{* *} \\
(37.060)\end{array}$ & $\begin{array}{c}-196.309^{* *} \\
(99.346)\end{array}$ & - & - & $\begin{array}{l}15.937^{\star \star} \\
(5.766)\end{array}$ & - & - & - & - & $\begin{array}{l}79.569^{\star \star} \\
(35.310)\end{array}$ & - \\
\hline USSPREAD ${ }_{t}$ & - & - & - & - & - & $\begin{array}{c}-0.498^{\star \star} \\
(0.186)\end{array}$ & - & - & - & - & - & - \\
\hline LNDEBTGDP*USSPREAD $_{t}$ & - & - & $\begin{array}{l}-1.023^{\star \star} \\
(0.309)\end{array}$ & - & $\begin{array}{l}0.478^{\star \star} \\
(0.141)\end{array}$ & $\begin{array}{l}2.420^{\star \star} \\
(0.674)\end{array}$ & $\begin{array}{c}-1.035^{\star \star} \\
(0.357)\end{array}$ & $\begin{array}{l}0.698^{\star \star} \\
(0.270)\end{array}$ & - & - & - & - \\
\hline ONOFFDIF*USSPREAD $_{t}$ & - & $\begin{array}{l}3.182^{\star \star} \\
(0.988)\end{array}$ & $\begin{array}{l}-0.347^{\star} \\
(0.188)\end{array}$ & - & $\begin{array}{l}-0.540^{\star} \\
(0.300)\end{array}$ & - & $\begin{array}{l}0.905^{\star \star} \\
(0.312)\end{array}$ & $\begin{array}{l}2.181^{\star \star} \\
(0.952)\end{array}$ & - & - & - & - \\
\hline ONOFFDIF2 $^{*}$ USSPREAD $_{t}$ & $\begin{array}{l}-1.433^{\star \star} \\
(0.607)\end{array}$ & $\begin{array}{c}-20.695^{\star \star} \\
(7.289)\end{array}$ & - & $\begin{array}{l}-4.101^{* *} \\
(2.024)\end{array}$ & - & - & $\begin{array}{l}15.428^{* *} \\
(4.988)\end{array}$ & $\begin{array}{l}10.449^{\star} \\
(5.801)\end{array}$ & - & - & - & - \\
\hline BIDASKDIF $^{\star} U S S P R E A D_{t}$ & $\begin{array}{l}-0.865^{\star \star} \\
(0.422) \\
\end{array}$ & $\begin{array}{c}-1.915^{\star *} \\
(2.339)\end{array}$ & - & $\begin{array}{c}-1.198^{* *} \\
(0.451)\end{array}$ & - & - & - & - & - & - & $\begin{array}{l}4.374^{\star \star} \\
(1.922) \\
\end{array}$ & - \\
\hline BIDASKDIF2*USSPREAD $_{t}$ & $\begin{array}{c}17.454^{\star \star} \\
(9.925)\end{array}$ & $\begin{array}{l}68.083^{\star *} \\
(47.263)\end{array}$ & - & - & - & $\begin{array}{c}-30.827^{\star *} \\
(9.752)\end{array}$ & - & - & - & - & $\begin{array}{c}-68.230^{* *} \\
(30.098)\end{array}$ & $\begin{array}{c}-12.434^{* *} \\
(6.051)\end{array}$ \\
\hline CONSTANT & - & $\begin{array}{l}0.371^{\star *} \\
(0.160)\end{array}$ & - & - & - & - & - & - & $\begin{array}{l}-0.141^{* *} \\
(0.030)\end{array}$ & - & - & $\begin{array}{c}-0.212^{\star *} \\
(0.079)\end{array}$ \\
\hline Number of obs & 1804 & 513 & 508 & 783 & 1686 & 517 & 442 & 727 & 1225 & 450 & 442 & 783 \\
\hline$F=$ & 222.24 & 108.44 & 55.48 & 148.21 & 134.82 & 114.47 & 54.13 & 83.23 & 79.96 & 196.6 & 57.23 & 88.39 \\
\hline Prob $>$ F = & 0.00 & 0.00 & 0.00 & 0.00 & 0.00 & 0.00 & 0.00 & 0.00 & 0.00 & 0.00 & 0.00 & 0.00 \\
\hline
\end{tabular}

** Significant at 5 percent confidence level.

*Significant at 10 percent confidence level. 